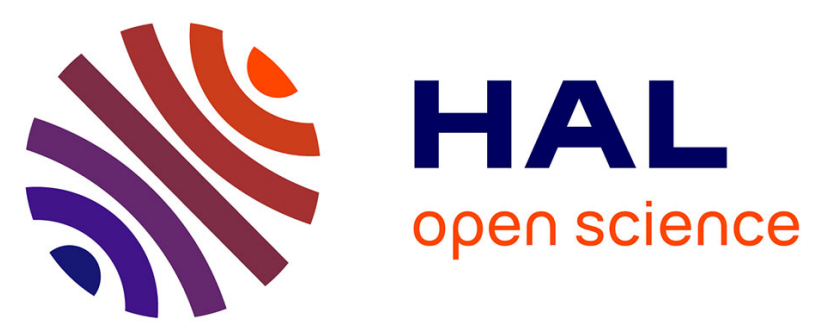

\title{
Innovative low temperature regenerable zinc based mixed oxide sorbents for synthesis gas desulfurization
}

Vincent Girard, David Chiche, Arnaud Baudot, Delphine Bazer-Bachi, Isabelle Clémençon, Florent Moreau, Christophe Geantet

\section{- To cite this version:}

Vincent Girard, David Chiche, Arnaud Baudot, Delphine Bazer-Bachi, Isabelle Clémençon, et al.. Innovative low temperature regenerable zinc based mixed oxide sorbents for synthesis gas desulfurization. Fuel, 2015, 140, pp.453 - 461. 10.1016/j.fuel.2014.09.090 . hal-01100617

\section{HAL Id: hal-01100617 https://hal.science/hal-01100617}

Submitted on 6 Jan 2015

HAL is a multi-disciplinary open access archive for the deposit and dissemination of scientific research documents, whether they are published or not. The documents may come from teaching and research institutions in France or abroad, or from public or private research centers.
L'archive ouverte pluridisciplinaire HAL, est destinée au dépôt et à la diffusion de documents scientifiques de niveau recherche, publiés ou non, émanant des établissements d'enseignement et de recherche français ou étrangers, des laboratoires publics ou privés. 


\title{
Innovative low temperature regenerable zinc based mixed oxide sorbents for synthesis gas desulfurization
}

\author{
Vincent Girard, ${ }^{a, b}$ David Chiche, ${ }^{* a}$ Arnaud Baudot, ${ }^{a}$ Delphine Bazer-Bachi, ${ }^{a}$ Isabelle \\ Clémençon, ${ }^{a}$ Florent Moreau ${ }^{a}$ and Christophe Geantet ${ }^{b}$
}

\begin{abstract}
${ }^{a}$ IFP Energies nouvelles, Rond-point de l'échangeur de Solaize, BP 3, 69360 Solaize, France
${ }^{b}$ Institut de Recherches sur la Catalyse et l'Environnement de Lyon (IRCELYON), UMR5256 CNRS - Université Lyon I, 2 avenue Albert Einstein, 69626 Villeurbanne cedex, France
\end{abstract}

* To whom correspondence should be addressed. E-mail: david.chiche@ifpen.fr, Tel.: +334 37702289

\section{Abstract}

Zinc oxide-based materials are commonly used for the final desulfurization of synthesis gas in IGCC and Fischer-Tropsch based XTL processes. The formation of large amount of solid waste is the major issue of this process. In-situ oxidative regeneration is a promising way to reduce this waste formation and enhance desulfurization process efficiency and economics. However, previous studies showed that one of the major drawbacks of oxidative regeneration of sulfided oxides relies in the high operating temperature range required to overcome the formation of inhibitory sulfate phases. A preliminary work of the authors focused on single oxides identified that regeneration temperature of zinc oxide-based sorbent could be reduced through the addition of molybdenum oxide. Two composites oxides - a single oxides mixture $\left(\mathrm{ZnO}\right.$ and $\left.\mathrm{MoO}_{3}\right)$ and a mixed oxide $\left(\mathrm{ZnMoO}_{4}\right)$ - were synthesized and characterized. Their sulfidation and oxidative regeneration properties were investigated through thermogravimetry and in-situ characterizations. Sulfidation of the single oxides mixture was shown to be similar to the combination of the sulfidation of both independent single oxides. Mixed oxide sulfidation leads to $\mathrm{ZnMoO}_{4}$ phase demixing into $\mathrm{ZnS}, \mathrm{MoS}_{2}$ and $\mathrm{ZnMoO}_{3}$. The oxidative regenerations of the sulfided single oxide mixtures and mixed oxide are initiated, respectively, at $350^{\circ} \mathrm{C}$ and $300^{\circ} \mathrm{C}$. These temperatures are $250^{\circ} \mathrm{C}$ and $300^{\circ} \mathrm{C}$ lower than the regeneration temperature of a pure $\mathrm{ZnS}$. For the sulfided mixed oxide regeneration is even complete at 
$500^{\circ} \mathrm{C}$ under isothermal conditions. Regeneration of sulfided oxides mixture and mixed oxide was thus shown to exhibit synergetic effects, resulting from exothermic oxidative reactions of molybdenum phases. Heat energy released during these reactions is assumed to enhance $\mathrm{ZnS}$ oxidation kinetics at a temperature lower than the previously measured one.

\section{Highlights}

- $\mathrm{ZnO}$ and $\mathrm{MoO}_{3}$ based materials have been studied as regenerable sulfur sorbents.

- Composite oxides show regeneration temperature up to $300^{\circ} \mathrm{C}$ lower than $\mathrm{ZnO}$ sorbents.

- Transitional phases formations were evidenced through in situ XRD.

- Regeneration of sulfided mixed oxide is shown to exhibit synergetic effects.

- Synergetic effects result from exothermic oxidative reactions of molybdenum phases.

\section{Keywords}

Desulfurization, synthesis gas, purification, sorbents regeneration 


\section{Introduction}

Integrated Gasification Combined Cycles (IGCC) power generation processes and FischerTropsch based XTL processes (XTL for X=Biomass, Coal, or Gas To Liquids) constitute efficient and cleaner alternative technologies for future energy production. ${ }^{1-3}$ Both technologies are based on a first step of feed gasification into a synthesis gas or syngas, composed mainly of a mixture of $\mathrm{CO}$ and $\mathrm{H}_{2} \cdot{ }^{4}$ In IGCC processes, the syngas is burnt into a gas turbine to produce electrical energy. In the XTL processes, the syngas is converted into hydrocarbon fuel via the Fischer-Tropsch reaction. ${ }^{5-7}$ Hydrogen sulfide constitutes one of the main impurities of synthesis gases. ${ }^{8}$ This compound mixed to $\mathrm{H}_{2}$, is responsible for the corrosion of the industrial units, ${ }^{9}$ especially the combustion turbine blades used in the IGCC. On another hand, it is also a poison of Fischer-Tropsch catalysts (cobalt-, iron-, and ruthenium-based) because of its irreversible chemisorption on their active sites. ${ }^{10-12}$ Therefore, the sulfur content specifications in syngas are very drastic for such industrial units, below 10 ppmv for IGCC ${ }^{13,14}$ and 0.05 ppmv for XTL. ${ }^{15,16}$ Syngas bulk desulfurization is commonly conducted by chemical or physical solvents, ${ }^{17,18}$ though these technologies do not allow to achieve complete $\mathrm{H}_{2} \mathrm{~S}$ removal. Indeed, expected $\mathrm{H}_{2} \mathrm{~S}$ syngas content at solvent-based acid gas removal systems outlet (in the range $0.1-1$ mol. ppm) remains higher than sulfur syngas content tolerated at Fischer-Tropsch process inlet. ${ }^{8,11}$ Therefore deep desulfurization of syngas is generally achieved with solid sorbents based on metal oxides which can irreversibly react with $\mathrm{H}_{2} \mathrm{~S}$ according to the following generic reaction:

$$
\mathrm{Me}_{\mathrm{x}} \mathrm{O}_{\mathrm{y}}(\mathrm{s})+\mathrm{y} \mathrm{H} \mathrm{H}_{2} \mathrm{~S}(\mathrm{~g}) \rightarrow \mathrm{Me}_{\mathrm{x}} \mathrm{S}_{\mathrm{y}}(\mathrm{s})+\mathrm{y} \mathrm{H}_{2} \mathrm{O}(\mathrm{g})
$$

Because of the important and various initial amounts of $\mathrm{H}_{2} \mathrm{~S}$ (1 to $\left.10000 \mathrm{ppm}\right),{ }^{19}$ the drastic sulfur specifications required, and the large syngas flow rates to be treated (around 100 $\mathrm{kg} . \mathrm{s}^{-1}$ for an IGCC power plant), ${ }^{20}$ the use of metal oxides based sorbents imposes either huge amounts of solids with large reactor or the use of small reactors and frequent changes of solid sorbent. In both cases, the large amount of solid waste produced is the major disadvantage of the sorbent-based syngas desulfurization, and may also alter process operation, efficiency, and economics. The in-situ regeneration of the sulfided sorbent, back to the oxide phase, during the process is an identified solution to improve desulfurization processes.

The optimization of such regenerable $\mathrm{H}_{2} \mathrm{~S}$ sorbent should be guided by two main targets: (1) offering irreversible sulfidation reaction when in contact with $\mathrm{H}_{2} \mathrm{~S}$ in order to minimize to the lowest possible level the $\mathrm{H}_{2} \mathrm{~S}$ concentration in the syngas, and (2) being able 
to get back to the oxide state when in contact with $\mathrm{O}_{2}$ at the lowest possible temperature. The sulfidation and oxidative regeneration properties of single oxides were studied in the literature through thermochemical calculations. ${ }^{21-24}$ It could be concluded from these studies that the single oxide sulfidation reaction was strongly affected by the syngas reductive atmosphere. Under these conditions, $\mathrm{ZnO}$ can be reduced into $\mathrm{Zn}$ which volatilized above $600^{\circ} \mathrm{C}^{25}$ reductions of $\mathrm{CuO},{ }^{26} \mathrm{Fe}_{\mathrm{x}} \mathrm{O}_{\mathrm{y}},{ }^{27}$ and $\mathrm{Mn}_{\mathrm{x}} \mathrm{O}_{\mathrm{y}}{ }^{28}$ are faster than the related sulfidation reactions. Moreover, the sulfidation of $\mathrm{Cu}$ or $\mathrm{Fe}$ and the reduced manganese oxide are kinetically limited. $^{26,27,29}$ The sulfidation equilibrium of $\mathrm{CeO}_{2}$ in reductive atmosphere seems to be favorable and leads to the formation of $\mathrm{Ce}_{2} \mathrm{O}_{2} \mathrm{~S} .{ }^{30}$

However, the formation and thermal stability of refractory sulfate phases in oxidative regeneration conditions were pointed out as the main issues of this regeneration process. ${ }^{24,31-33}$ Indeed sulfate formation leads to a decrease of the sorbent reactivity and durability, ${ }^{29,34,35}$ and detrimental particles sintering is favored at the high regeneration temperature required for sulfate decomposition. ${ }^{36}$ Furthermore, the high temperatures required for the sulfate decomposition will affect the overall thermal efficiency of the process and will impose the use of refractory alloys to manufacture the industrial reactors. ${ }^{20}$

In order to overcome the limitations of single oxide-based sorbents, "composite oxide sorbents" such as for example zinc ferrite $\left(\mathrm{ZnFe}_{2} \mathrm{O}_{4}\right),{ }^{37}$ zinc titanate $\left(\mathrm{Zn}_{\mathrm{x}} \mathrm{Ti}_{\mathrm{y}} \mathrm{O}_{\mathrm{x}+2 \mathrm{y}}\right),{ }^{38}$ or copper chromite $\left(\mathrm{CuO}-\mathrm{CrO}_{2}\right)^{39}$ were developed through a series of incremental improvements in order to stabilize the long-term performance of $\mathrm{H}_{2} \mathrm{~S}$ sorbent, ${ }^{40}$ optimize the operating conditions of the process, ${ }^{41}$ and decrease the regeneration temperature below $500^{\circ} \mathrm{C} .{ }^{41-44}$

In a previous work, ${ }^{45}$ a global approach was proposed to study the physical and chemical phenomena involved during both sulfidation and regeneration steps of single oxides and corresponding sulfides by a confrontation between thermochemical calculations and experimental approaches. Some single oxides were thus identified to design a low temperature regenerable $\mathrm{H}_{2} \mathrm{~S}$ sorbent. In particular, zinc oxide was shown to exhibit high sulfidation ability and restricted sulfate formation upon the $\mathrm{ZnS}$ surface particles during the oxidative regeneration process, in comparison to other sulfides of transition metal such as copper, manganese or iron. $\mathrm{MoO}_{3}$ shown attractive properties, as the oxidative regeneration of the sulfided $\mathrm{MoO}_{3}$ occurs through fast, highly exothermic and complete reaction below $500^{\circ} \mathrm{C}$.

Regarding the distinct properties of these two metal oxides, we focus, in this paper on the reactivity of two different zinc and molybdenum based materials: a $\mathrm{ZnO}$ and $\mathrm{MoO}_{3}$ single oxides physical mixture and the $\mathrm{ZnMoO}_{4}$ mixed oxide. The objectives of this work are to evaluate the difference between the two materials and to identify potential synergetic effects 
between zinc and molybdenum phases, to study the physical and chemical phenomenon involved in sulfidation and oxidative regeneration reactions of these materials, and to validate the global approach previously proposed.

\section{Materials and Methods}

\subsection{Oxide materials syntheses}

The single oxides mixture, $\mathrm{ZnO}-\mathrm{MoO}_{3}$ was obtained by physical milling of $\mathrm{MoO}_{3}$ and $\mathrm{ZnO}$ materials. $\mathrm{ZnO}$ material was synthesized from thermal decomposition of precursor at $500^{\circ} \mathrm{C}$ for 2 hours. The precursor was $\left(\mathrm{ZnCO}_{3}\right)_{2} \cdot\left(\mathrm{Zn}(\mathrm{OH})_{2}\right)_{3}$ (Aldrich, purity > 58\% $\left.\mathrm{Zn}\right) \cdot \mathrm{MoO}_{3}$ precursor was obtained from a chemical supplier, and was used as received after material characterizations.

Mixed oxide $\mathrm{ZnMoO}_{4}$ material was synthesized by successive calcinations steps at $450^{\circ} \mathrm{C}$ and $500^{\circ} \mathrm{C}$ and physical milling of the previous $\mathrm{ZnO}-\mathrm{MoO}_{3}$ single oxides mixture.

\subsection{Thermogravimetry measurements}

The sulfidation of the composite oxides was followed by thermogravimetric analysis (TGA) at $350^{\circ} \mathrm{C}$ and atmospheric pressure, using a commercial magnetic suspension balance (Rubotherm). The feed was composed of $0.9 \% \mathrm{H}_{2} \mathrm{~S}$ diluted in $\mathrm{H}_{2}$ with a constant flow (10.8 NL. $\mathrm{h}^{-1}$ ). Oxide samples were firstly heated under a Helium flow up to $350^{\circ} \mathrm{C}$, and then the inlet valve was switched to the $\mathrm{H}_{2} \mathrm{~S}-\mathrm{H}_{2}$ mixture under isothermal conditions. Sulfidation step had been conducted for 12 hours.

Oxidative regeneration reaction of the sulfided sorbents were followed by TGA-DSC (Netzsch STA-449C Jupiter). Experiments with linear temperature variation were conducted by heating sulfided samples in an oxidative gas mixture $\left(5 \% \mathrm{O}_{2}\right.$ in $\left.\mathrm{N}_{2}\right)$ at $5^{\circ} \mathrm{C} / \mathrm{min}$ from $49^{\circ} \mathrm{C}$ to $625^{\circ} \mathrm{C}$. Isothermal experiments were also conducted on sulfided samples, which were first heated at $5^{\circ} \mathrm{C} / \mathrm{min}$ to $500^{\circ} \mathrm{C}$ under $\mathrm{N}_{2}$, and then treated at $500^{\circ} \mathrm{C}$ by an oxidative gas mixture $\left(5 \% \mathrm{O}_{2}\right.$ in $\mathrm{N}_{2}$ ) for 2 hours. This gas mixture composition was chosen to limit sulfate formation. ${ }^{45}$ In both kinds of experiments, gas flow rate was set to 9 NL.h ${ }^{-1}$. The exhaust gases were analyzed by mass spectrometry (Netzsch QMS-430C Aeolos).

\subsection{Materials characterizations}

Materials crystalline phases were characterized by X-ray diffraction (XRD) using a PANalytical X'Pert PRO diffractometer operating with $\mathrm{CuK}_{\alpha}$ radiation $(\lambda=1.54182 \AA)$. Materials textural properties were studied through the measurements of $\mathrm{Kr}$ or $\mathrm{N}_{2}$ adsorption 
isotherms at $77 \mathrm{~K}$, using a Micromeritics ASAP 2420 instrument. Specific surface areas were obtained using the BET model. Composition of sulfided and regenerated solids was determined by elemental analysis (Flash 2000 CHNS).

Scanning electron microscopy (SEM) observations were performed using a JEOL JSM-6340F (Field Emission Scanning Electron Microscope) apparatus operating at $1 \mathrm{kV}$. Transmission electron microscopy (TEM) observations and energy dispersive X-ray analysis (EDX) cartographies were performed with a TEM-EDX JEOL 2100-F- FEG (Field Emission Gun) instrument operating at $200 \mathrm{kV}$. TEM observations and EFTEM cartographies were performed with TEM-EFTEM JEOL 2100F instrument, equipped with a GATAN GIF Tridiem spectrometer. Particles observed by TEM were prepared by ultramicrotomy (70 nm thickness).

\subsection{In-situ XRD experiments}

Sulfidation and regeneration properties of the two studied composite oxides were investigated by in-situ XRD experiments using a PANalytical X'Pert PRO diffractometer operating with $\mathrm{CuK}_{\alpha}$ radiation $(\lambda=1.54182 \AA)$, and equipped with a XRF cell. The oxides were sulfided at $350^{\circ} \mathrm{C}$ with a $0.9 \% \mathrm{H}_{2} \mathrm{~S}$ in $\mathrm{H}_{2}$ gas mixture. This sulfided material was regenerated under air at $500^{\circ} \mathrm{C}$. Between each XRD acquisition, reacting gas was introduced for a restricted time, then reaction was stopped by a $\mathrm{N}_{2}$ flow before and during XRD measurements. This enabled to avoid any materials modification during measurements. During the sulfidation, XRD measurements were performed on materials after 10,20,40, 60, 240 and 420 minutes of reaction. During the regeneration, XRD measurements were performed after 2, 4, 6, 10, 15, 20 and 30 minutes of reaction. These durations were set from the analysis of the TGA data.

\section{Results and discussion}

\subsection{Oxides characterizations}

As shown in Fig. 1, the single oxides mixture is made of pure $\mathrm{ZnO}$ and $\mathrm{MoO}_{3}$. This solid is composed of small monocrystalline $\mathrm{ZnO}$ particles $(\sim 25-50 \mathrm{~nm})$ deposited on the surface of $\mathrm{MoO}_{3}$ platelets (100 $\mathrm{nm}$ to micrometer scale). This solid textural properties are in agreement with its measured specific surface area $\left(10 \mathrm{~m}^{2} \cdot \mathrm{g}^{-1}\right)$. The SEM micrograph (Fig. 2) indicated that $\mathrm{ZnO}$ particles are aggregated and mixed to or deposited on the $\mathrm{MoO}_{3}$ platelets. 


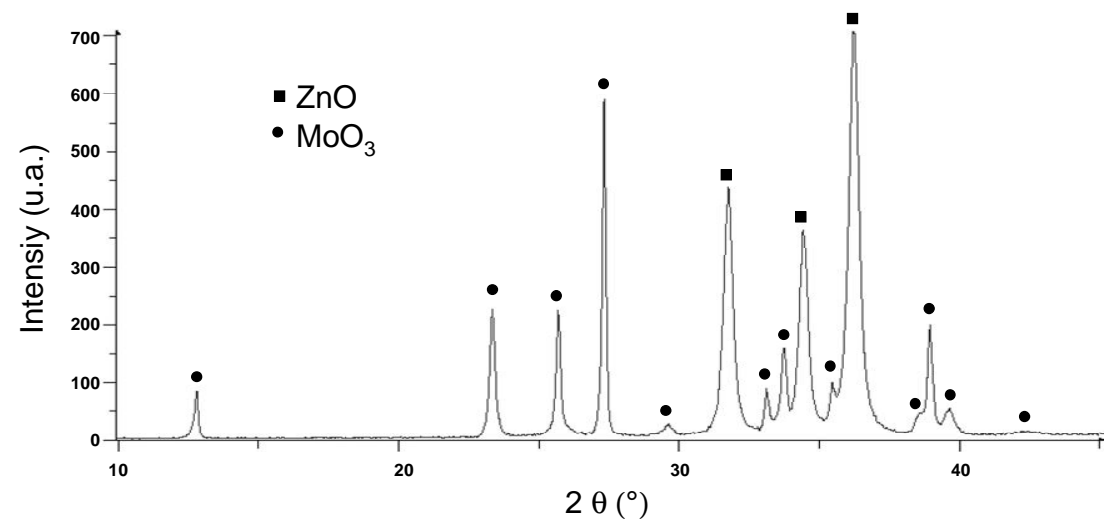

Fig. $1 \mathrm{XRD}$ pattern of the $\mathrm{ZnO}-\mathrm{MoO}_{3}$ solid.

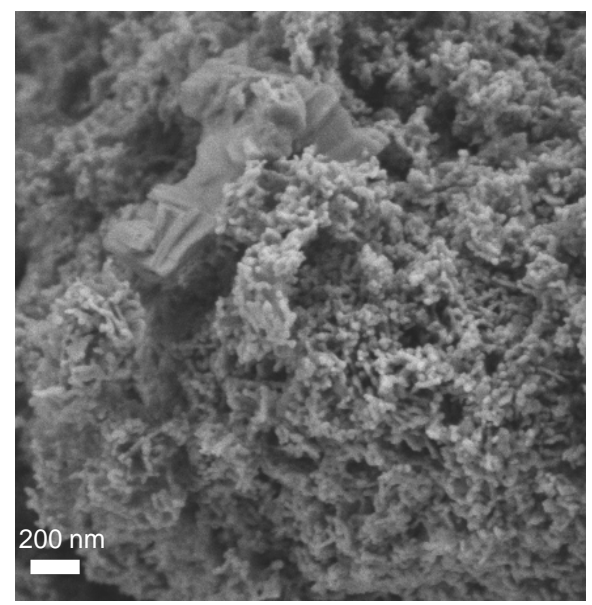

Fig. 2 SEM micrographs of $\mathrm{ZnO}-\mathrm{MoO}_{3}$.

The mixed oxide is composed of $\mathrm{ZnMoO}_{4}$ (Fig. 3). As presented on Fig. 4, it was made of micrometric spherical particles, formed by agglomerated and faceted grains (size below 500 $\mathrm{nm})$. Moreover, the textural properties of this solid are in agreement with the measured specific surface area $\left(<1 \mathrm{~m}^{2} \cdot \mathrm{g}^{-1}\right)$.

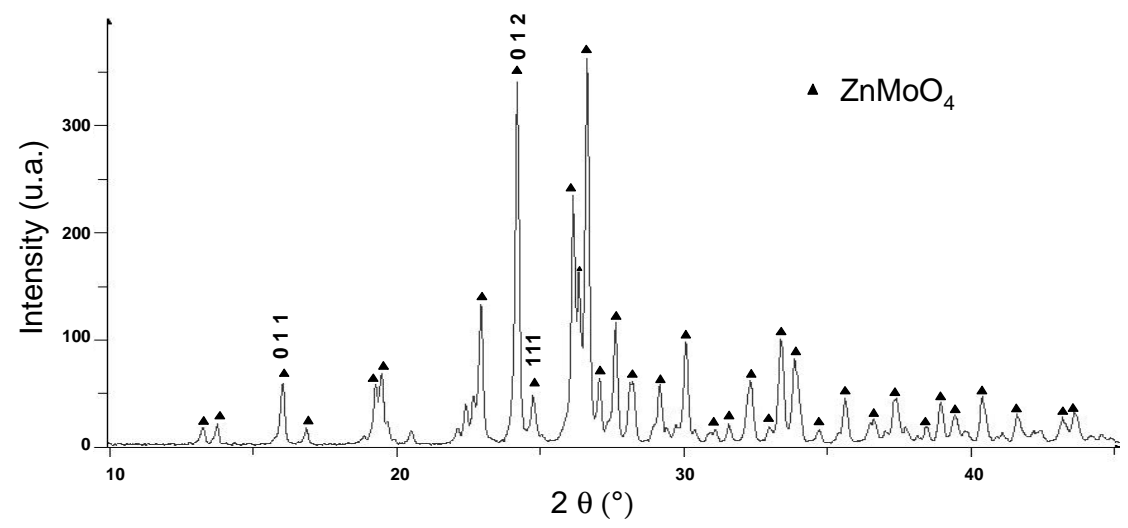

Fig. 3 XRD pattern of the mixed oxide. 


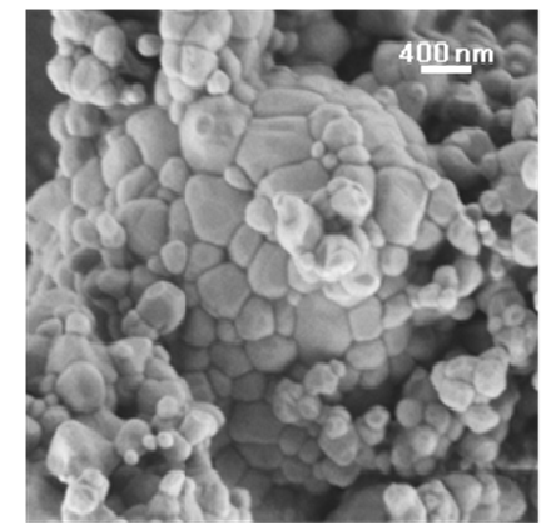

Fig. 4 SEM micrographs of $\mathrm{ZnMoO}_{4}$.

\subsection{Sulfidation studies}

Weight variations measured by TGA under sulfiding conditions as a function of time are represented for each composite oxide sample on Fig. 5. Whatever the solid, the weight variations were characterized by an abrupt weight loss followed by a gain.

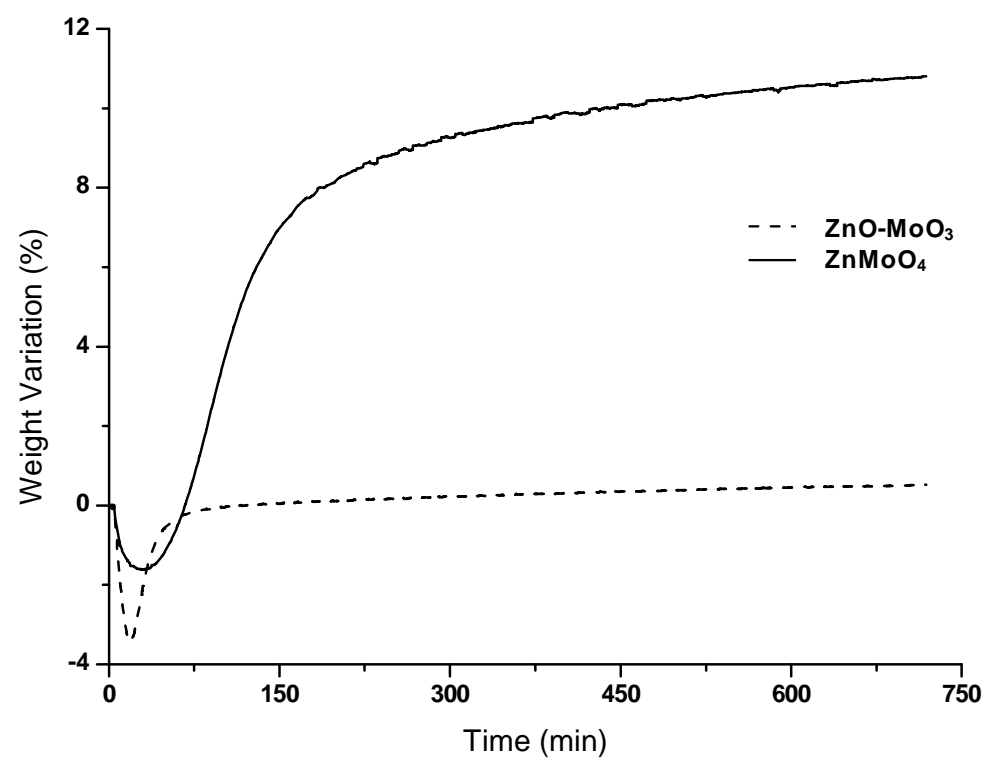

Fig. 5 Weight variations measured by TGA during the sulfidation at $350{ }^{\circ} \mathrm{C}$ with the gas mixture $0.9 \% \mathrm{H}_{2} \mathrm{~S}-\mathrm{H}_{2}$ during 12 hours, of the two sorbents:-- - $\mathrm{ZnO}-\mathrm{MoO}_{3}$ and $-\mathrm{ZnMoO}_{4}$.

The sulfidation of the $\mathrm{ZnO}-\mathrm{MoO}_{3}$ mixture led to a solid composed by the following crystalline phases: $\mathrm{ZnS}, \mathrm{MoO}_{2}$ and $\mathrm{MoS}_{2}$ (Fig. 6A), while the sulfidation of $\mathrm{ZnMoO}_{4}$ mixed oxide led to the formation of $\mathrm{ZnS}, \mathrm{MoS}_{2}$ and $\mathrm{ZnMoO}_{3}$ (Fig. 6B). 


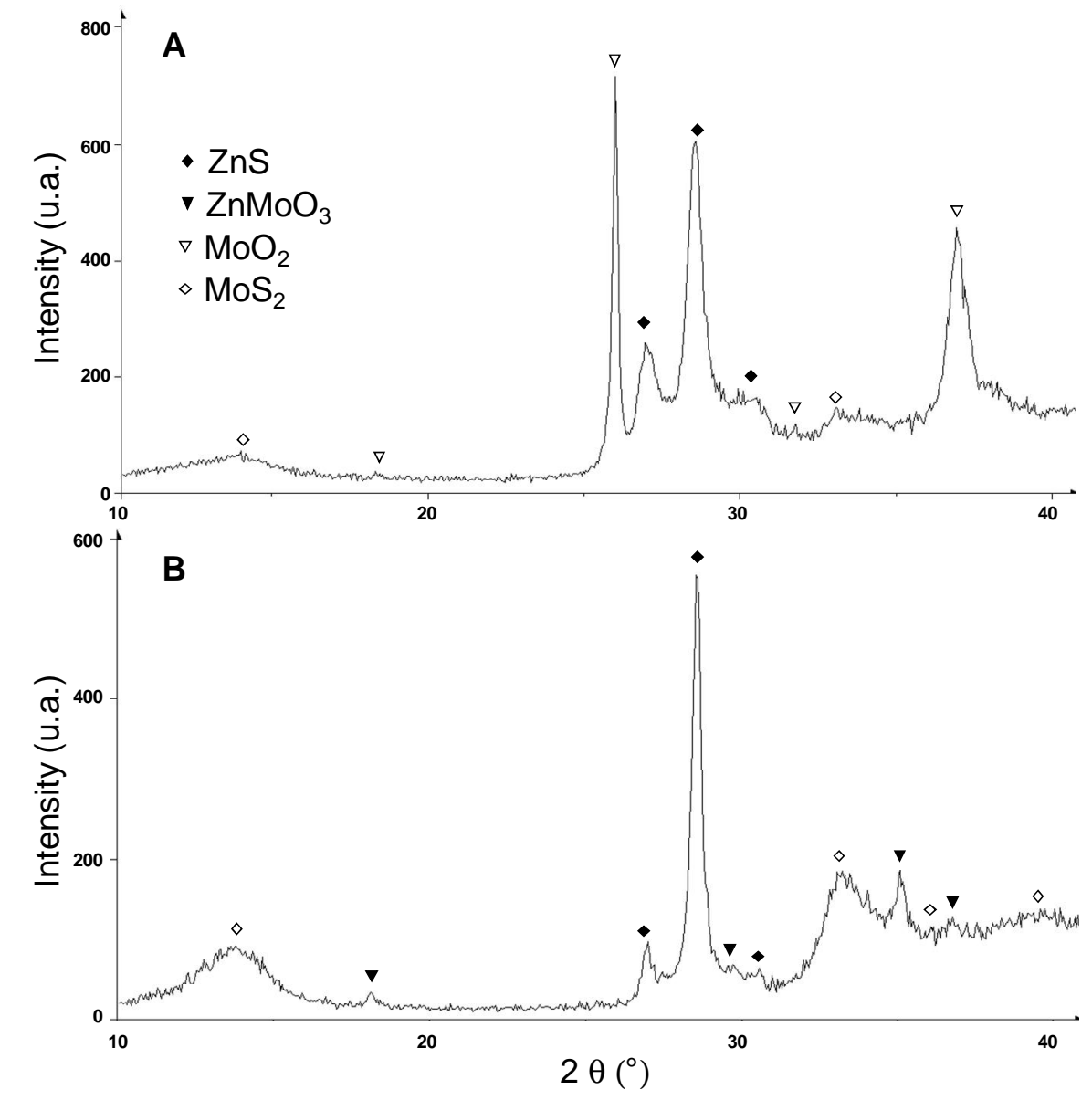

Fig. 6 XRD patterns of the sulfided $\mathrm{ZnO}-\mathrm{MoO}_{3}(\mathrm{~A})$ and $\mathrm{ZnMoO}_{4}(\mathrm{~B})$.

TGA measurements were completed by in-situ XRD analyses performed on the composite oxides. As it can be seen on Fig. 7 for the $\mathrm{ZnO}-\mathrm{MoO}_{3}$ single oxides mixture sulfidation at $350^{\circ} \mathrm{C}, \mathrm{MoO}_{3}$ was both reduced and sulfided into $\mathrm{MoO}_{2}$ and $\mathrm{MoS}_{2} ;{ }^{46}$ while $\mathrm{ZnO}$ was sulfided into $\mathrm{ZnS} .^{47,48}$ Under the same conditions, $\mathrm{ZnMoO}_{4}$ mixed oxide is simultaneously reduced into $\mathrm{ZnMoO}_{3}$ and sulfided into $\mathrm{ZnS}$ and $\mathrm{MoS}_{2}$ (Cf. Fig. 8). 


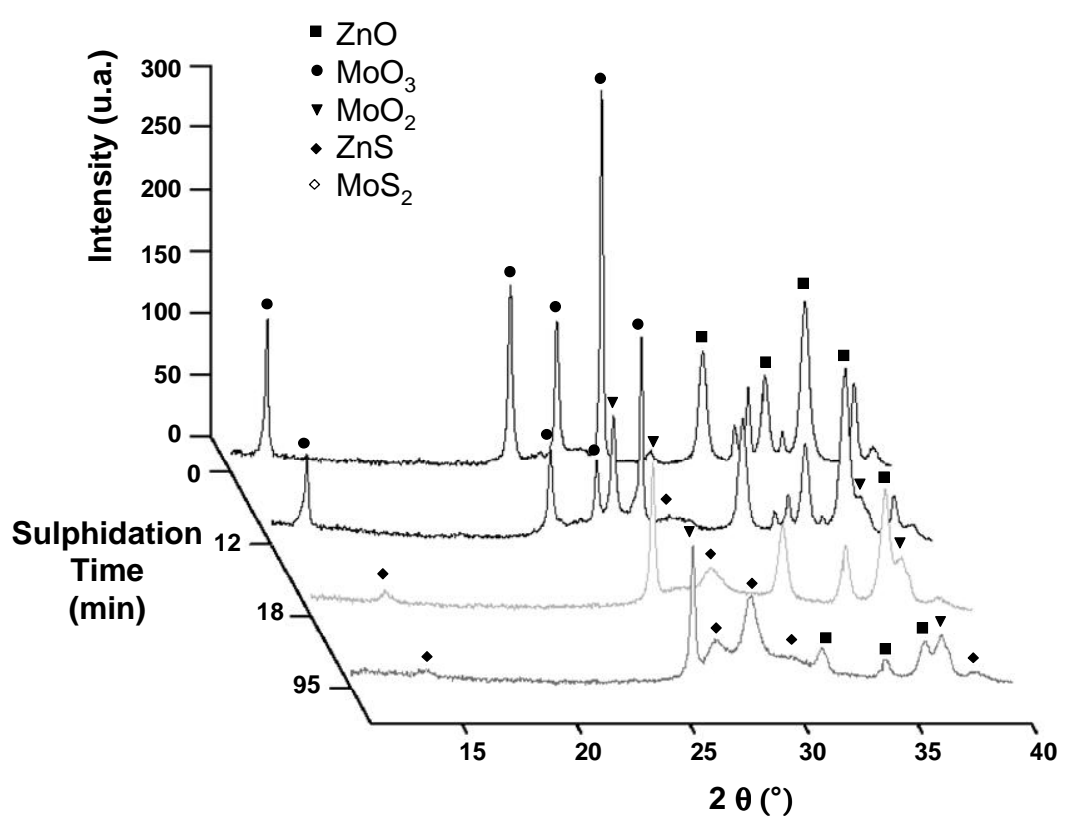

Fig. 7 In-situ XRD sequence for the $\mathrm{ZnO}-\mathrm{MoO}_{3}$ against sulfidation time at $350^{\circ} \mathrm{C}$ with the gas mixture $0.9 \% \mathrm{H}_{2} \mathrm{~S}-99.1 \% \mathrm{H}_{2}$. For the sake of clarity, XRD patterns are not all presented.

Consequently the initial weight losses, measured by TGA, could be attributed to the reductions of $\mathrm{MoO}_{3}$ and $\mathrm{ZnMoO}_{4}$ into $\mathrm{MoO}_{2}$ and $\mathrm{ZnMoO}_{3}$. However, it appeared that the reduction process was incomplete for both solids, as the experimental weight losses were lower than theoretical weight losses anticipated (-7wt.\% for the reduction of both materials). The following weight gains could be due to the sulfidation of these compounds into $\mathrm{MoS}_{2}$ and $\mathrm{ZnS}$. To conclude, in agreement with the in-situ XRD experiments, the sulfidation and reduction reactions occurred simultaneously for both solids under the chosen operating conditions. 


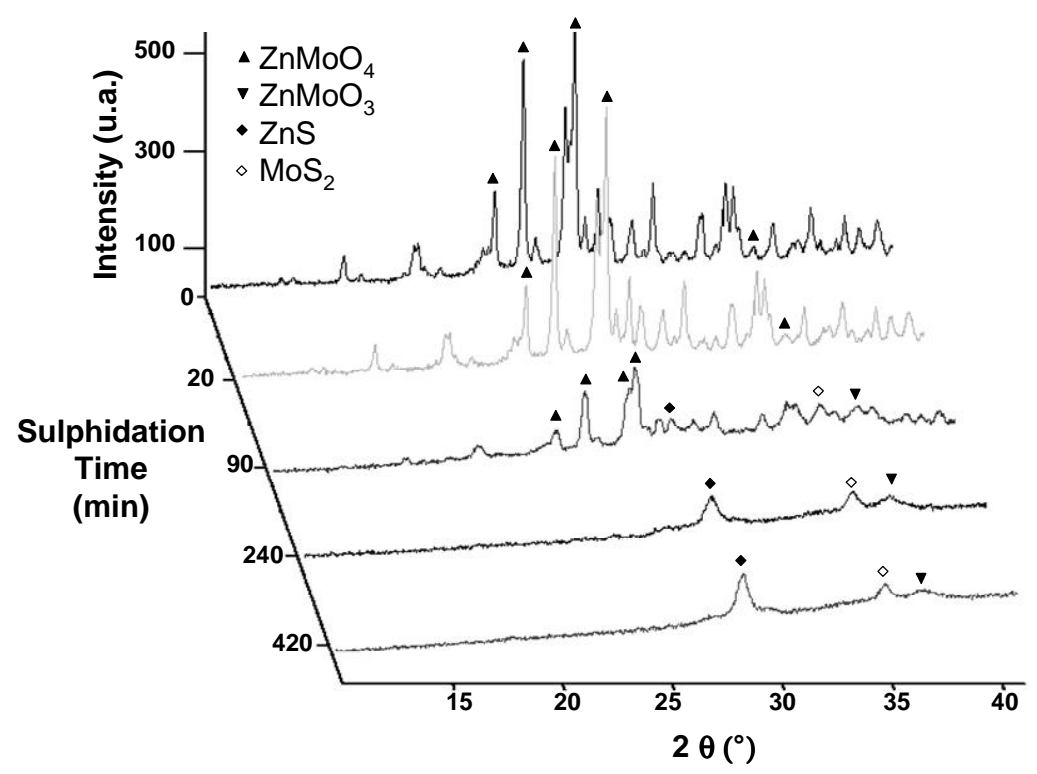

Fig. 8 In-situ XRD sequence for $\mathrm{ZnMoO}_{4}$ against sulfidation time at $350^{\circ} \mathrm{C}$ with the gas mixture $0.9 \% \mathrm{H}_{2} \mathrm{~S}$ $99.1 \% \mathrm{H}_{2}$. For the sake of clarity, XRD patterns are not all presented.

\subsection{Textural properties of the sulfided composites oxides}

The characteristics of the sulfided sorbents are summarized in Table 1. The specific surface area of the sulfided $\mathrm{ZnO}-\mathrm{MoO}_{3}$ increased during the sulfidation reaction. This result agrees with our previous study. ${ }^{45}$ The specific surface area does not evolve during the sulfidation of the mixed oxide. As previously observed, ${ }^{40,49}$ the addition of molybdenum and the formation of the mixed phase $\mathrm{ZnMoO}_{4}$ might stabilize the textural properties during the sulfidation steps.

The sulfur sorption capacity (Table 1) is more important in the sulfided $\mathrm{ZnMoO}_{4}$ mixed oxide than in the other sorbent. Assuming zinc reactivity is the same, this result might be explained by a more important formation of $\mathrm{MoS}_{2}$ during the sulfidation of $\mathrm{ZnMoO}_{4}$.

Table 1 Structural and textural properties of the sulfided sorbents.

\begin{tabular}{|c|c|c|}
\hline & $\begin{array}{l}\text { Sulfided } \mathrm{ZnO}-\mathrm{MoO}_{3} \text { single } \\
\text { oxides mixture }\end{array}$ & $\begin{array}{c}\text { Sulfided } \mathrm{ZnMoO}_{4} \text { mixed } \\
\text { oxide }\end{array}$ \\
\hline Crystalline phases (XRD) & $\begin{array}{c}\mathrm{ZnS} \\
\mathrm{MoO}_{2}, \mathrm{MoS}_{2}\end{array}$ & $\begin{array}{l}\mathrm{ZnMoO} \\
\mathrm{ZnS}, \mathrm{MoS}_{2}\end{array}$ \\
\hline Specific surface area & $\begin{array}{c}23 \mathrm{~m}^{2} \cdot \mathrm{g}^{-1} \\
\left(\mathrm{~N}_{2} \text { adsorption isotherm }\right)\end{array}$ & $\begin{array}{c}2 \mathrm{~m}^{2} \cdot \mathrm{g}^{-1} \\
(\mathrm{Kr} \text { adsorption isotherm })\end{array}$ \\
\hline $\begin{array}{l}\text { Sulfur uptake capacity } \\
\text { (Weight \%) }\end{array}$ & 19 & 31 \\
\hline
\end{tabular}


SEM images of the sulfided $\mathrm{ZnO}-\mathrm{MoO}_{3}$ single oxides mixture are shown in Fig. 9. Small particles, with sizes close to the initial $\mathrm{ZnO}$ particles ones can be observed, could be $\mathrm{ZnS}$ particles. These particles may form 10 microns aggregates or may be deposited on the surface of facetted crystals, probably $\mathrm{MoO}_{2}$. $\mathrm{MoS}_{2}$ layers can also be observed. ${ }^{50}$ SEM and TEM images for the sulfided $\mathrm{ZnMoO}_{4}$ are shown in Fig. 10. As the initial $\mathrm{ZnMoO}_{4}$, micrometric aggregates, can be observed. Moreover, a shell can also be observed. The TEM micrographs indicate that the shell is around $50 \mathrm{~nm}$ thickness and constituted by agglomerated and facetted grains. It is surrounding a core $(300-500 \mathrm{~nm})$ with numerous $\mathrm{MoS}_{2}$ layers. This study was completed by EDX and EFTEM mappings reported on Fig. 11. The different images shown indicate that the shell facetted grains are composed of $\mathrm{ZnS}$. Such a layer was previously observed during the sulfidation of $\mathrm{ZnO}^{47,48,51}$ and $\mathrm{Mo}\left(2.5\right.$ wt.\%) containing $\mathrm{Zn}_{2} \mathrm{TiO}_{4}{ }^{35}$ Moreover, the core is mainly composed of $\mathrm{MoS}_{2}$, but few parts characterized by sulfur atoms depletion are richer in oxygen, even though zinc atoms are not detected inside the core of the observed particles. These parts might be attributed to the reduced mixed phase $\mathrm{ZnMoO}_{3}$.

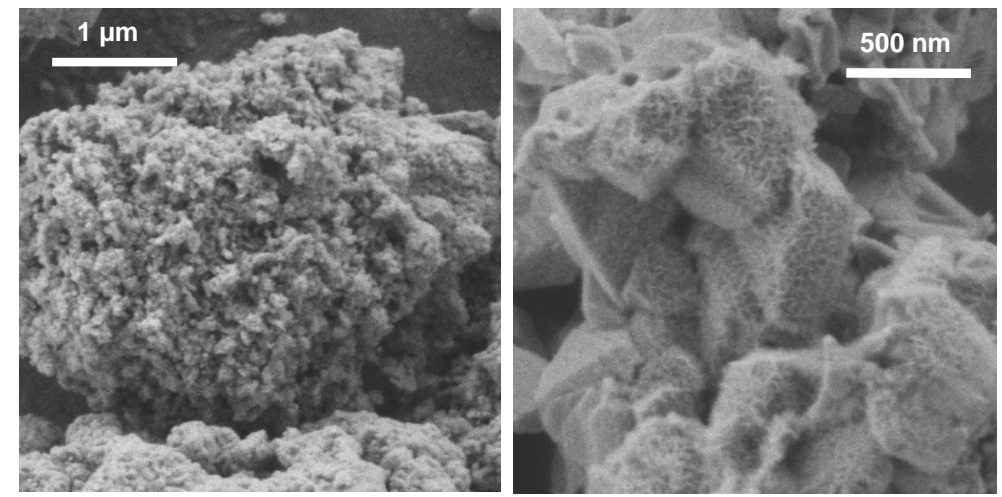

Fig. 9 SEM micrographs of sulfided $\mathrm{ZnO}-\mathrm{MoO}_{3}$ single oxides mixture. 


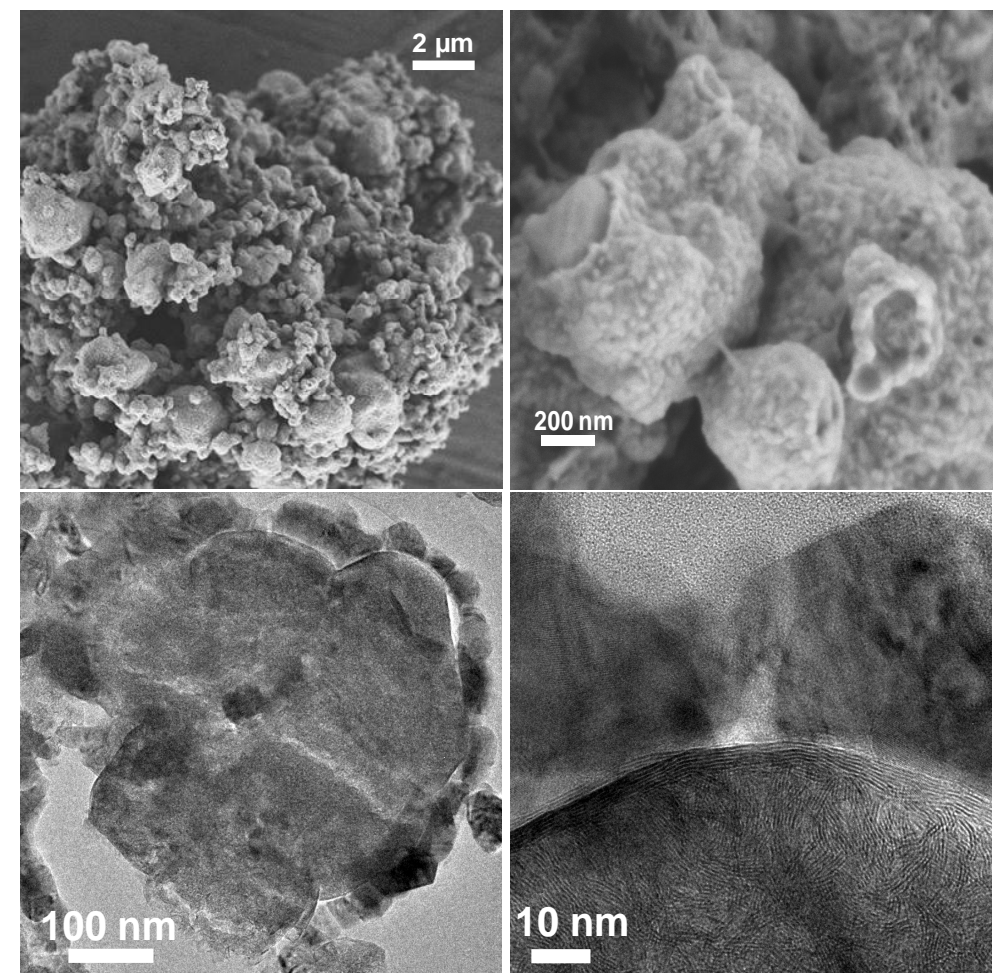

Fig. 10 SEM and TEM micrographs of sulfided $\mathrm{ZnMoO}_{4}$ mixed oxide.

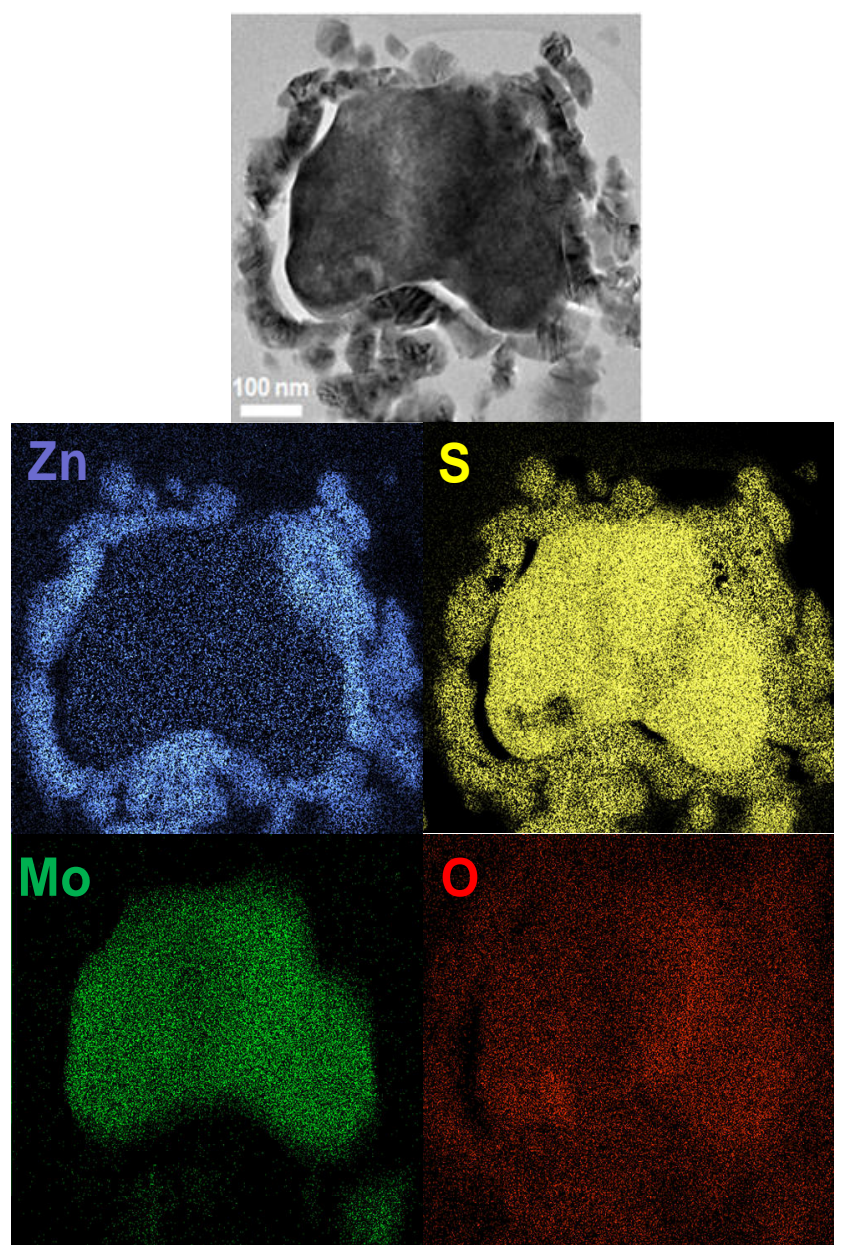

Fig. 11 TEM micrograph of the sulfided $\mathrm{ZnMoO}_{4}$ mixed oxide; EFTEM mappings of zinc and sulfur atoms; EDX mappings of molybdenum $\left(\mathrm{K} \alpha_{1}=17.441 \mathrm{keV}\right)$ and oxygen $\left(\mathrm{K} \alpha_{1}=0.441 \mathrm{keV}\right)$ atoms. 


\subsection{Sulfidation mechanism}

As schematized in Fig. 12, the reactivity of $\mathrm{ZnO}-\mathrm{MoO}_{3}$ single oxides mixture is equivalent to the combination of the two independent single oxides $\mathrm{ZnO}$ and $\mathrm{MoO}_{3}$. $\mathrm{ZnO}$ is sulfided into $\mathrm{ZnS}$ thanks to a growth mechanism with an outward development, ${ }^{47,48,51}$ due to zinc and oxygen solid-state diffusion through the $\mathrm{ZnS}$ layer and the formation of cavities at the $\mathrm{ZnS} / \mathrm{ZnO}$ internal interface. This phenomenon results from the Kirkendall effect. ${ }^{52}$ Bulk $\mathrm{MoO}_{3}$ sulfidation mechanism is also well known, ${ }^{46,53}$ and implies first the formation of the oxisulfide $\mathrm{MoOS}_{2}$ phase, which decomposition leads to surface $\mathrm{MoS}_{2}$ layers formation. The bulk of $\mathrm{MoO}_{3}$ particles is reduced into $\mathrm{MoO}_{2}$.
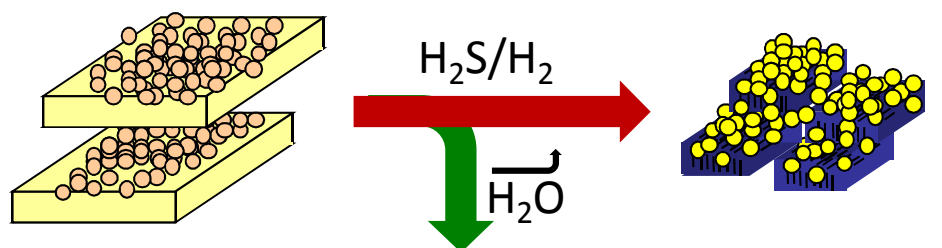

Fig. 12 Schematic representation of the $\mathrm{ZnO}-\mathrm{MoO}_{3}$ single oxides mixture sulfidation process. $\mathrm{ZnO}$ : light brown spheres, $\mathrm{MoO}_{3}$ : light yellow platelets; $\mathrm{ZnS}$ : dark yellow spheres, $\mathrm{MoO}_{2}$ : blue boxes, $\mathrm{MoS}_{2}$ : black lines.

Under reductive and sulfiding conditions, the mixed oxide phase $\mathrm{ZnMoO}_{4}$ is demixed into the reduced mixed oxide phase $\mathrm{ZnMoO}_{3}$ and the sulfided phases $\mathrm{ZnS}$ and $\mathrm{MoS}_{2}$ (Fig 13). The mechanisms involved in phase demixing were not clearly identified. However, the outward development of $\mathrm{ZnS}$ might be the result of a kinetic competition between internal and external diffusion of species involved in the sulfidation reaction. ${ }^{51}$ The $\mathrm{MoS}_{2}$ core might be the result of the $\mathrm{ZnMoO}_{3}$ sulfidation. Indeed, various studies on mixed oxide outlined the different reactivity between the single oxide and the mixed oxide, such as $\mathrm{CuO},{ }^{26,29} \mathrm{CuCr}_{\mathrm{x}} \mathrm{O}_{2 \mathrm{x}}{ }^{39}$ and $\mathrm{CuAl}_{2} \mathrm{O}_{4} \cdot{ }^{54}$

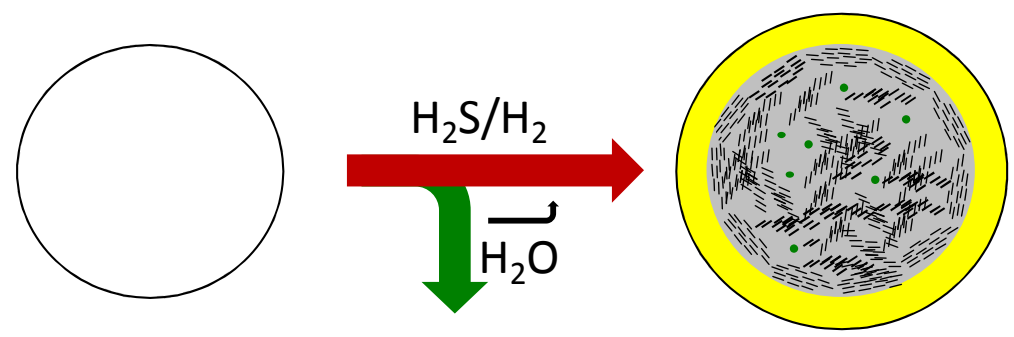

Fig. 13 Schematic representation of the mixed oxide $\mathrm{ZnMoO}_{4}$ material sulfidation process. $\mathrm{ZnMoO}_{4}$ : white sphere; $\mathrm{ZnS}$ in yellow, $\mathrm{MoS}_{2}$ : black lines on gray surface, $\mathrm{ZnMoO}_{3}$ : green dots. 


\subsection{Oxidative regeneration reactions study under temperature increase}

TGA-DSC and mass spectrometry analyses for the oxidative regenerations of the sulfided single oxides mixture and mixed oxide materials are presented, respectively, in Fig. 14 and 15. The weight variations differ and are accompanied by different exothermic reactions and $\mathrm{SO}_{2}(\mathrm{~g})$ releases. Consequently, from these data (beginning of $\mathrm{SO}_{2}(\mathrm{~g})$ releases), regeneration reactions start for sulfided $\mathrm{ZnO}-\mathrm{MoO}_{3}$ and $\mathrm{ZnMoO}_{4}$ materials at, respectively, 350 and $300^{\circ} \mathrm{C}$.

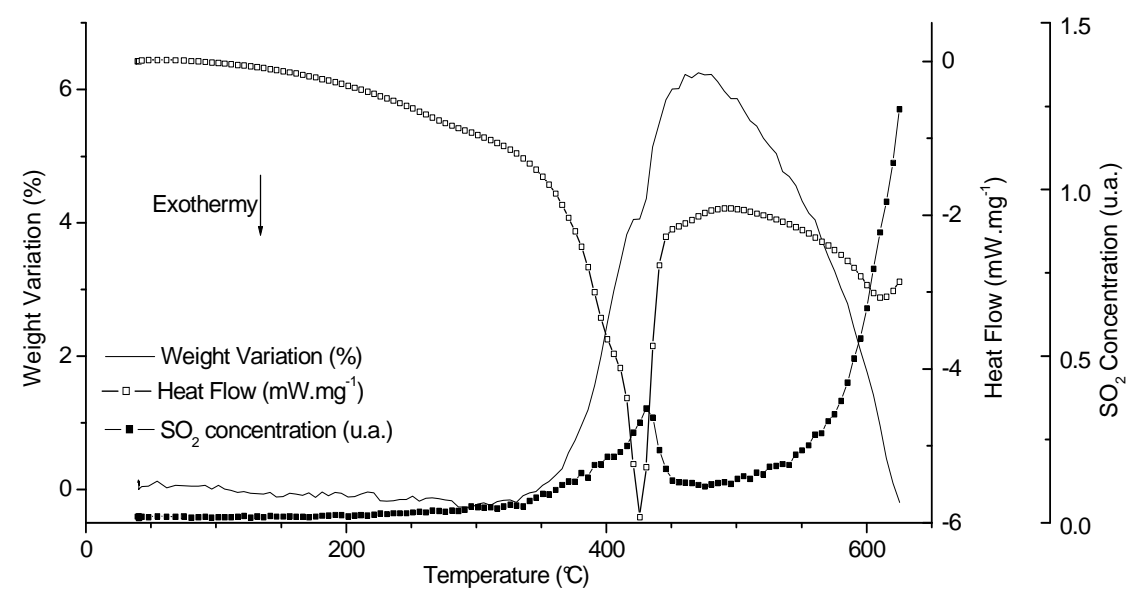

Fig. 14 TGA-DSC and mass spectrometry analysis during the regeneration step between 40 and $625^{\circ} \mathrm{C}$ in $5 \% \mathrm{O}_{2}$ $\mathrm{N}_{2}$ of the sulfided $\mathrm{ZnO}-\mathrm{MoO}_{3}$ single oxides mixture.

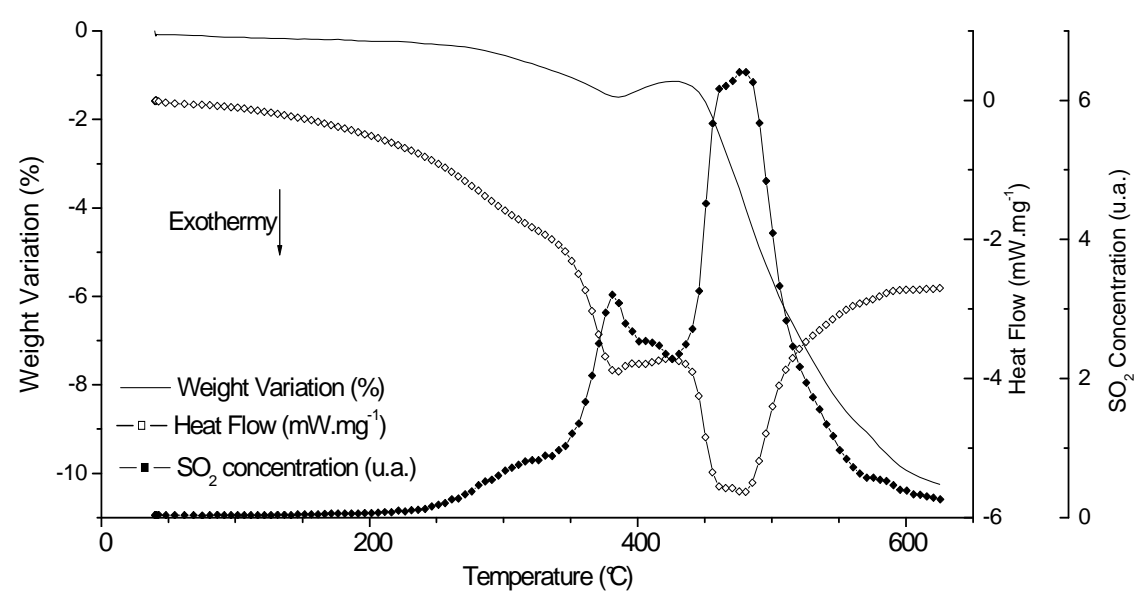

Fig. 15 TGA-DSC and mass spectrometry analysis during the regeneration step between 40 and $625^{\circ} \mathrm{C}$ in $5 \% \mathrm{O}_{2^{-}}$ $\mathrm{N}_{2}$ of the sulfided $\mathrm{ZnMoO}_{4}$ mixed oxide.

No sulfur was detected by the elemental analysis indicating the complete regeneration of the two sulfided materials back to oxide phases. The XRD patterns of the regenerated $\mathrm{ZnO}-\mathrm{MoO}_{3}$ (Fig. 16) and $\mathrm{ZnMoO}_{4}$ (Fig. 17) evidence the presence of the mixed oxide phase $\mathrm{ZnMoO}_{4}$. 
$\mathrm{MoO}_{3}$ is also detected in the regenerated single oxide mixture; it indicates that $\mathrm{MoO}_{3}$ was likely to be over stoechiometric in the original oxide.

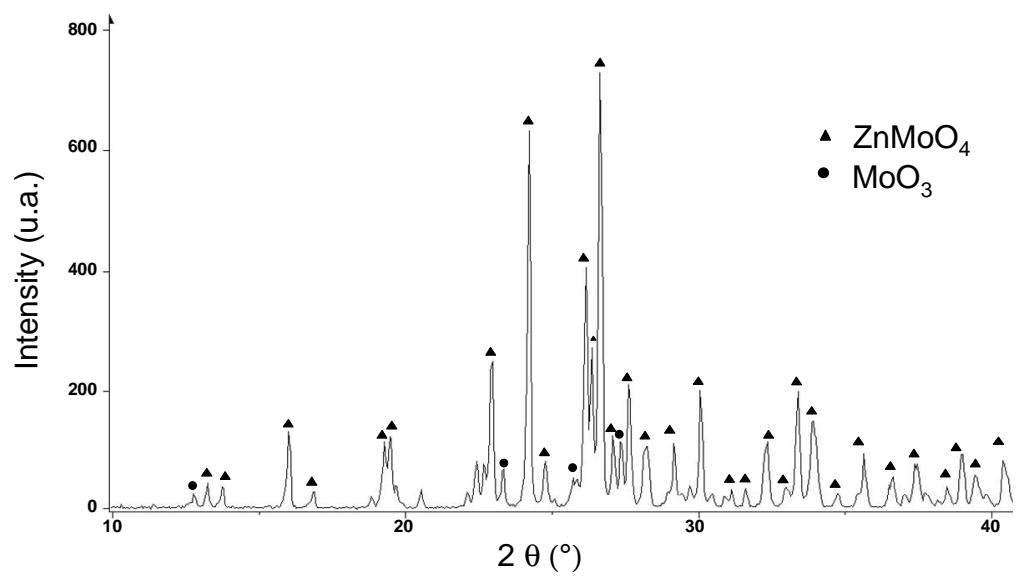

Fig. $16 \mathrm{XRD}$ pattern of the regenerated $\mathrm{ZnO}-\mathrm{MoO}_{3}$ at $625^{\circ} \mathrm{C}$ under $5 \% \mathrm{O}_{2}-\mathrm{N}_{2}$.

For both solids, it is believed that the first exothermic events are linked to the molybdenum phases $\left(\mathrm{MoS}_{2}, \mathrm{MoO}_{2}\right.$ and $\left.\mathrm{ZnMoO}_{3}\right)$ oxidations into $\mathrm{MoO}_{3}$ and $\mathrm{ZnMoO}_{4}$. Then, the second exothermic event, characterized by a weight loss and a release of $\mathrm{SO}_{2}(\mathrm{~g})$, might be resulting from the $\mathrm{ZnS}$ oxidation into $\mathrm{ZnO}$ or $\mathrm{ZnMoO}_{4}$ in the presence of the molybdenum phases. Consequently, in these two solids, the $\mathrm{ZnS}$ oxidation could start at $470^{\circ} \mathrm{C}$ (sulfided $\mathrm{ZnO}$ $\mathrm{MoO}_{3}$ ) and $430^{\circ} \mathrm{C}$ (sulfided $\mathrm{ZnMoO}_{4}$ ). These temperatures are, respectively, $130^{\circ} \mathrm{C}$ and $170^{\circ} \mathrm{C}$ lower than the oxidation temperature of a pure $\mathrm{ZnS}$ material. ${ }^{45}$ Such combined thermal effect has been previously observed on a $\mathrm{Zn}_{2} \mathrm{TiO}_{4}$ promoted by $\mathrm{Co}$ and/or Ni. ${ }^{41,42,44}$

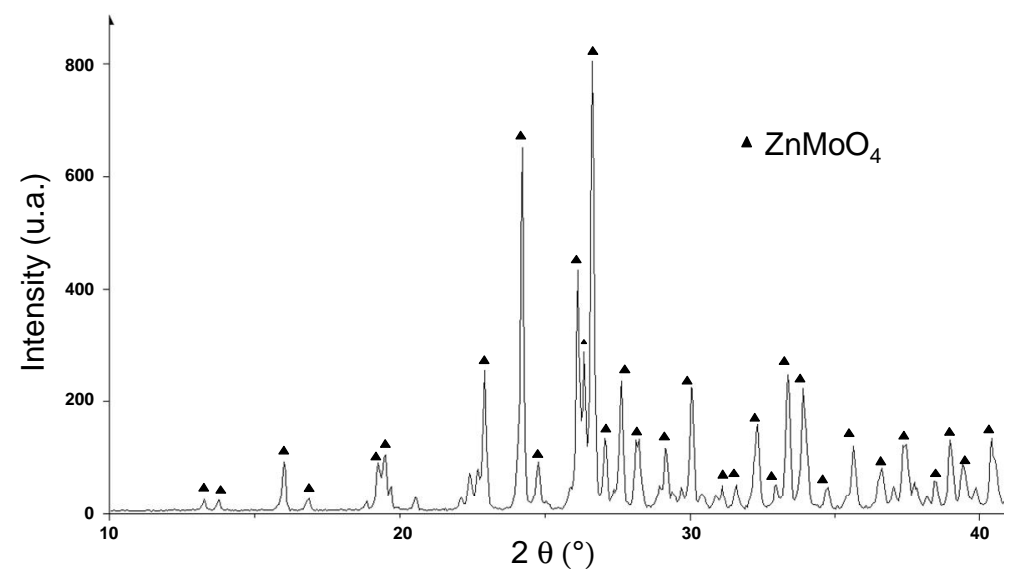

Fig. $17 \mathrm{XRD}$ pattern of the regenerated $\mathrm{ZnMoO}_{4}$ at $625^{\circ} \mathrm{C}$ under $5 \% \mathrm{O}_{2}-\mathrm{N}_{2}$. 


\subsection{Oxidative regeneration reactions study under isothermal conditions at $500^{\circ} \mathrm{C}$}

with $5 \% \mathrm{O}_{2}-\mathrm{N}_{2}$

TGA-DSC and mass spectrometry analyses for the oxidative regeneration under isothermal conditions at $500^{\circ} \mathrm{C}$ for both sulfided solids are presented in the Fig. 18 and 19. For both sulfided materials, the contact between the solid and the oxidizing gas mixture is characterized by an exothermic reaction and a release of $\mathrm{SO}_{2}(\mathrm{~g})$.

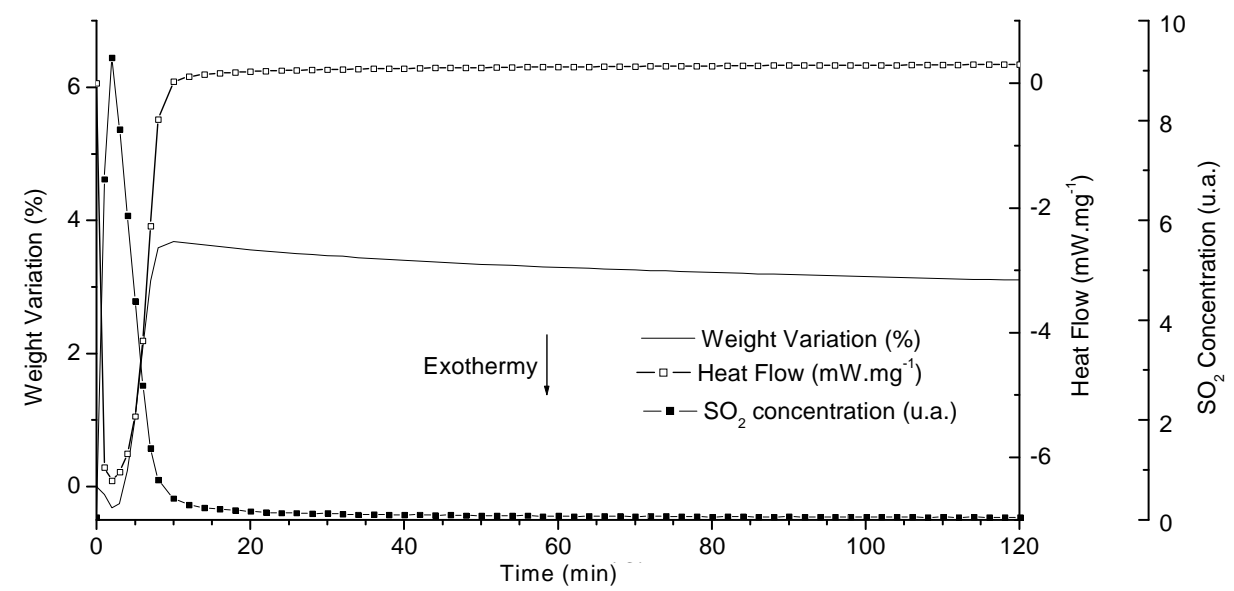

Fig 18 TGA-DSC and mass spectrometry analysis for sulfided $\mathrm{ZnO}-\mathrm{MoO}_{3}$ single oxides mixture regeneration step at $500^{\circ} \mathrm{C}$ under $5 \% \mathrm{O}_{2}-\mathrm{N}_{2}$.

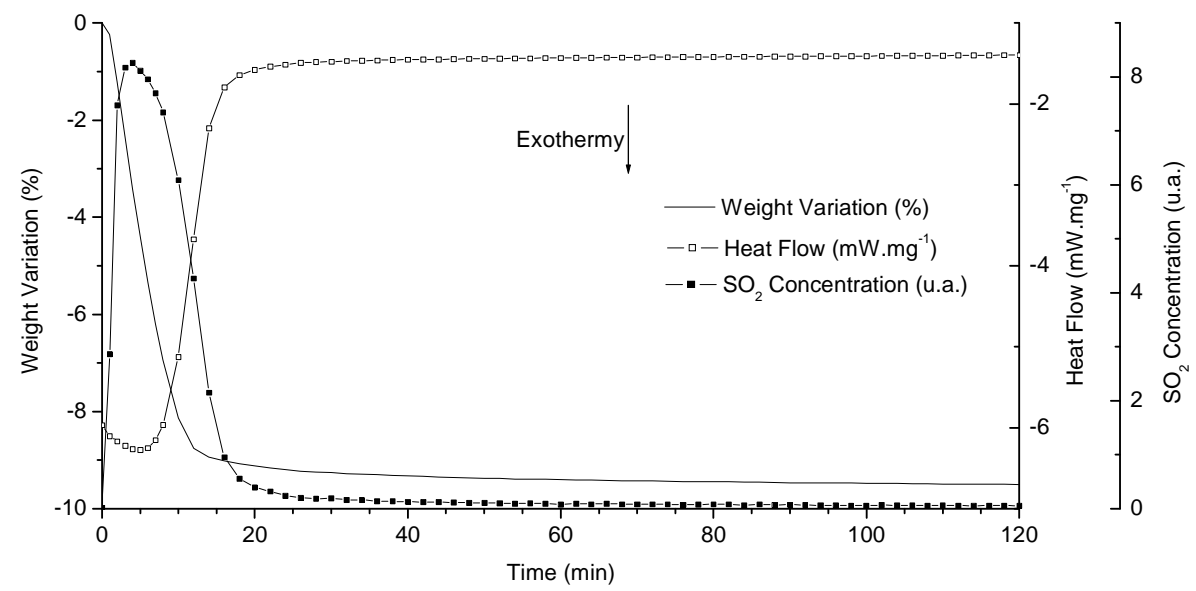

Fig. 19 TGA-DSC and mass spectrometry analysis for sulfided $\mathrm{ZnMoO}_{4}$ mixed oxide regeneration step at $500^{\circ} \mathrm{C}$ under $5 \% \mathrm{O}_{2}-\mathrm{N}_{2}$.

However, the weight variation during the experiment with the sulfided $\mathrm{ZnO}-\mathrm{MoO}_{3}$ is positive, indicating that the sulfided phases are not fully oxidized into oxide phases. This result is coherent with elemental analysis and XRD patterns of the solid obtained after the regeneration 
step under isothermal conditions at $500^{\circ} \mathrm{C}$ (Fig. 20). Indeed, $\mathrm{ZnS}$ phase is still detected on this regenerated solid, and 7 weight $\%$ of sulfur are measured through elemental analysis.

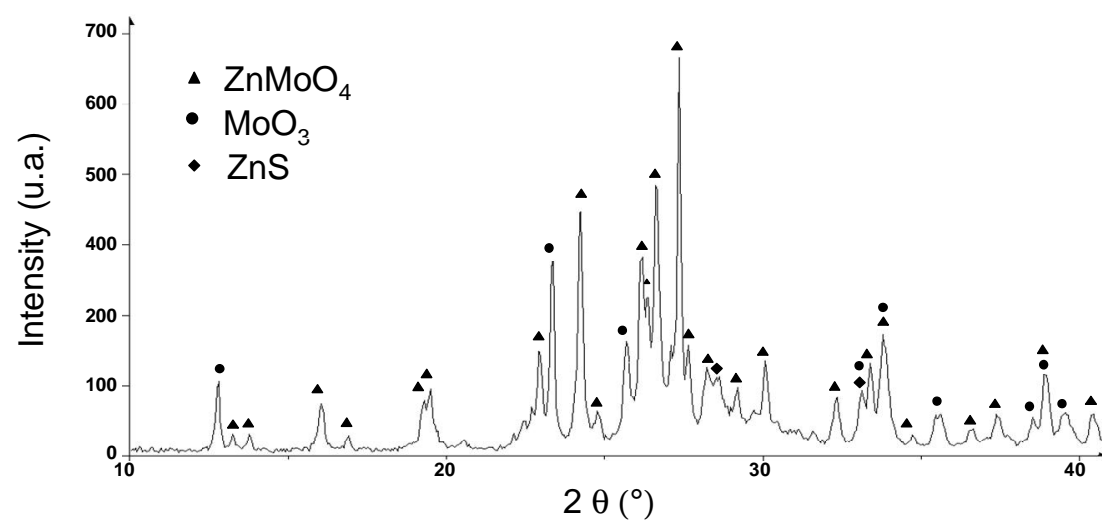

Fig. $20 \mathrm{XRD}$ pattern of the $\mathrm{ZnO}-\mathrm{MoO}_{3}$ single oxides mixture after the regeneration step under isothermal conditions at $500^{\circ} \mathrm{C}$ in $5 \% \mathrm{O}_{2}-\mathrm{N}_{2}$.

The study of the sulfided $\mathrm{ZnMoO}_{4}$ mixed oxide regenerated at $500^{\circ} \mathrm{C}$ outlined the full regeneration of this material into the $\mathrm{ZnMoO}_{4}$ starting oxide. Indeed, no sulfur and sulfided phases are detected by the elemental analysis and by XRD characterizations (Fig. 21).

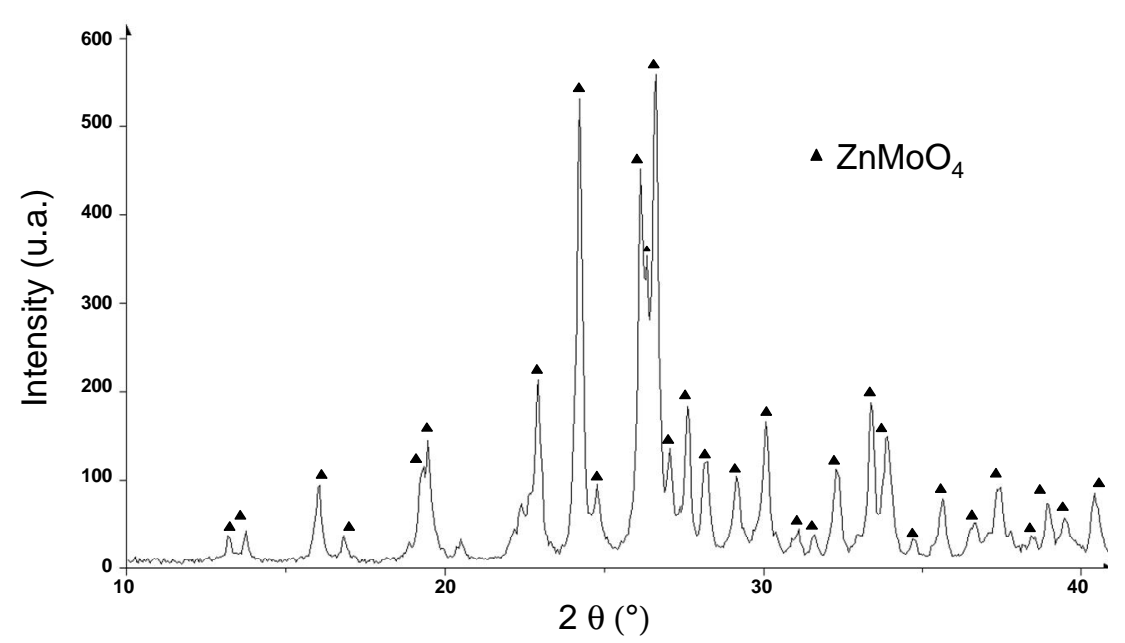

Fig. $21 \mathrm{XRD}$ pattern of $\mathrm{ZnMoO}_{4}$ mixed oxide after the regeneration step under isothermal conditions at $500^{\circ} \mathrm{C}$ in $5 \% \mathrm{O}_{2}-\mathrm{N}_{2}$.

These TGA measurements were completed by in-situ XRD characterizations performed on the sulfided composite oxides. XRD pattern evolutions (Fig. 22 and Fig. 23) highlighted the positive role of the molybdenum phases during the oxidation of the two sulfided solids at $500^{\circ} \mathrm{C}$ under $5 \% \mathrm{O}_{2}-\mathrm{N}_{2}$ gas mixture. 
$\mathrm{ZnMoO}_{3}, \mathrm{MoS}_{2}$ and $\mathrm{MoO}_{2}$ are firstly oxidized, respectively, into $\mathrm{ZnMoO}_{4}, \mathrm{MoO}_{2}{ }^{55}$ and $\mathrm{MoO}_{3}$. Then, $\mathrm{ZnS}$ phase seems to react with $\mathrm{MoO}_{3}$ and $\mathrm{O}_{2}(\mathrm{~g}$ ) (sulfided single oxides mixture) or with $\mathrm{MoO}_{2}$ and $\mathrm{O}_{2}(\mathrm{~g})$ (sulfided mixed oxide) to form a $\mathrm{ZnMoO}_{4}$ phase.

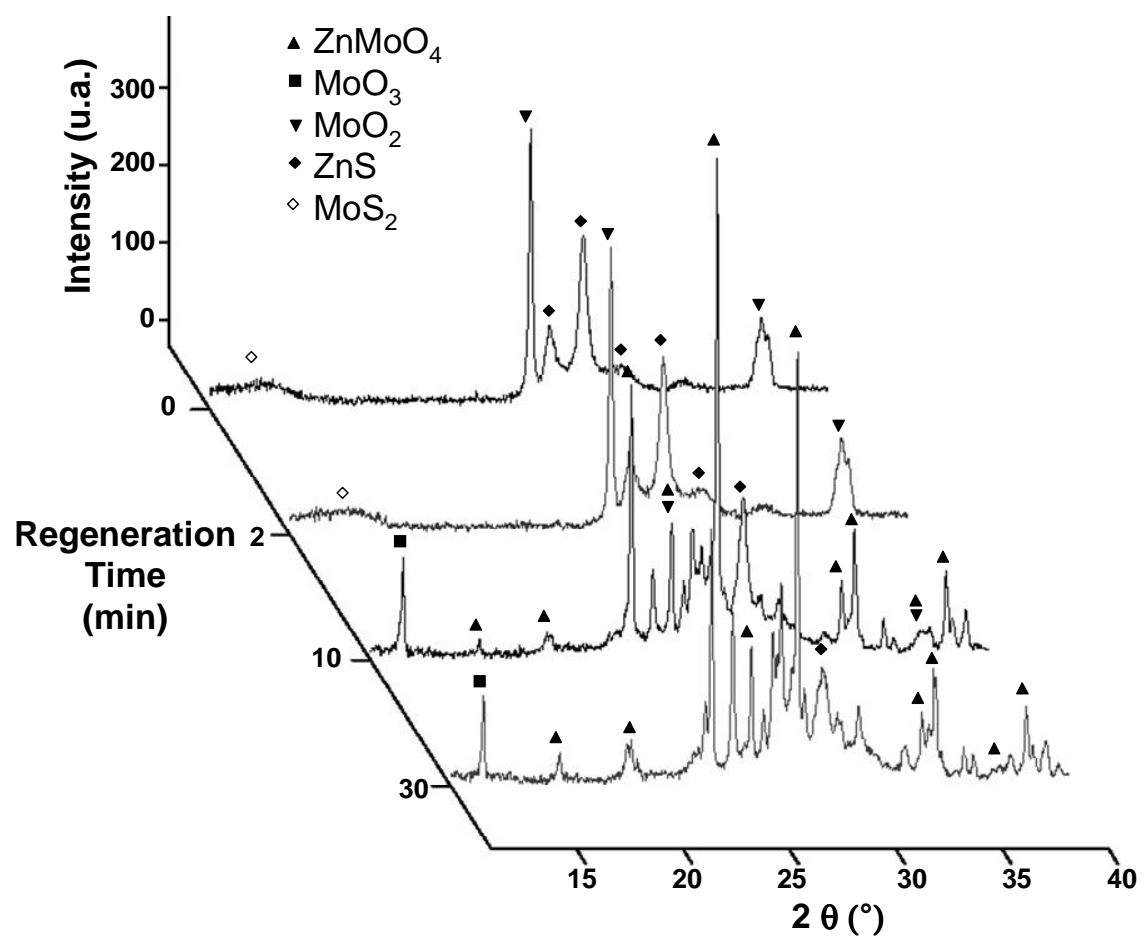

Fig. 22 In-situ XRD sequence for oxidative regeneration of the sulfided $\mathrm{ZnO}-\mathrm{MoO}_{3}$ single oxides mixture at $500{ }^{\circ} \mathrm{C}$ with $5 \% \mathrm{O}_{2}-\mathrm{N}_{2}$ gas mixture.

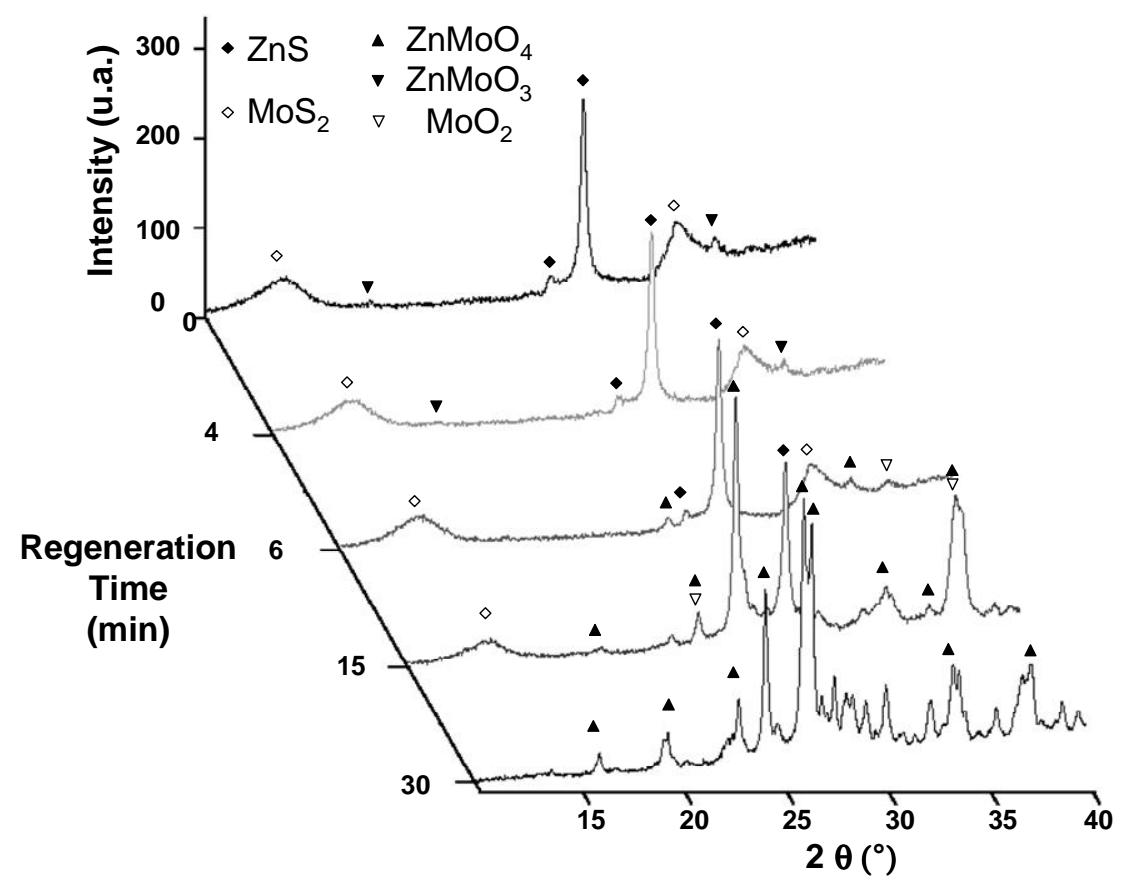

Fig. 23 In-situ XRD sequence for oxidative regeneration of the sulfided $\mathrm{ZnMoO}_{4}$ mixed oxide at $500^{\circ} \mathrm{C}$ with $5 \% \mathrm{O}_{2}-\mathrm{N}_{2}$ gas mixture. 


\subsection{Oxidative regeneration mechanism under isothermal conditions at $500^{\circ} \mathrm{C}$}

As schematized in Fig. 24 from SEM observations ( $C f$. Fig. 9), the sulfided $\mathrm{ZnO}-\mathrm{MoO}_{3}$ single oxides mixture is composed of aggregated $\mathrm{ZnS}$ particles coating the surface of $\mathrm{MoO}_{2} / \mathrm{MoS}_{2}$ facetted crystals. From in-situ XRD characterizations, the following reactions involved in the oxidative regeneration under isothermal conditions at $500^{\circ} \mathrm{C}$ could be suggested: contact between the solid and the oxidizing gas mixture initiates the oxidation reactions of $\mathrm{MoS}_{2}$ into $\mathrm{MoO}_{2}$ then $\mathrm{MoO}_{3}$. The heat released from these exothermic reactions might start a direct reaction between $\mathrm{ZnS}$, the freshly formed $\mathrm{MoO}_{3}$ and $\mathrm{O}_{2}$ to obtain $\mathrm{ZnMoO}_{4}$ phase, as the $\mathrm{ZnO}$ phase is not detected. This sequence can be summarized as: ${ }^{56}$

Firstly, $\mathrm{MoS}_{2}(\mathrm{~s})+3 \mathrm{O}_{2}(\mathrm{~g}) \rightarrow \mathrm{MoO}_{2}(\mathrm{~s})+2 \mathrm{SO}_{2}(\mathrm{~g})$,

$$
\Delta_{\mathrm{r}} \mathrm{H}=-302 \mathrm{~kJ} / \mathrm{mol} \text { of } \mathrm{O}_{2}(\mathrm{~g})
$$

then, $2 \mathrm{MoO}_{2}(\mathrm{~s})+\mathrm{O}_{2}(\mathrm{~g}) \rightarrow 2 \mathrm{MoO}_{3}(\mathrm{~s})$,

$$
\Delta_{\mathrm{r}} \mathrm{H}=-311 \mathrm{~kJ} / \mathrm{mol} \text { of } \mathrm{O}_{2}(\mathrm{~g})
$$

and, $2 \mathrm{ZnS}(\mathrm{s})+2 \mathrm{MoO}_{3}(\mathrm{~s})+3 \mathrm{O}_{2}(\mathrm{~g}) \rightarrow 2 \mathrm{ZnMoO}_{4}+2 \mathrm{SO}_{2}(\mathrm{~g})$,

$$
\Delta_{\mathrm{r}} \mathrm{H}=-370 \mathrm{~kJ} / \mathrm{mol} \text { of } \mathrm{O}_{2}(\mathrm{~g})
$$

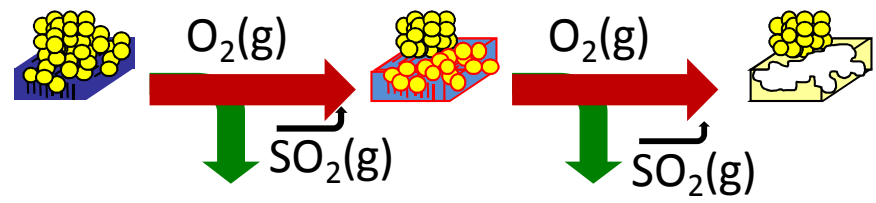

Fig 24 Schematic representation of the sulfided $\mathrm{ZnO}-\mathrm{MoO}_{3}$ single oxides regeneration process under isothermal conditions at $500^{\circ} \mathrm{C} . \mathrm{MoO}_{2}$ : blue boxes, $\mathrm{MoS}_{2}$ : black lines, $\mathrm{ZnS}$ : dark yellow spheres, Thermal energy: red lines, $\mathrm{MoO}_{3}$ : light yellow shapes; $\mathrm{ZnMoO}_{4}$ : white shape.

However, the presence of residual $\mathrm{ZnS}$ at the end of the TGA experiments indicates that the oxidative regeneration at $500^{\circ} \mathrm{C}$ of the sulfided single oxides mixture did not lead to a complete regeneration of pure oxide species. It can be explained by the strong heterogeneity of the sulfided sorbent.

As schematized in Fig. 25 from SEM observations ( $C f$. Fig. 10 and 11), the sulfided $\mathrm{ZnMoO}_{4}$ mixed oxide is composed by a $\mathrm{MoS}_{2}$ core mixed with $\mathrm{ZnMoO}_{3}$ phase, surrounded by a $\mathrm{ZnS}$ layer. The following reactions involved in the oxidative regeneration under isothermal conditions at $500^{\circ} \mathrm{C}$ could be proposed: the contact between the solid and the oxidizing gas mixture initiates the oxidation reactions of $\mathrm{MoS}_{2}$ and $\mathrm{ZnMoO}_{3}$ into, respectively, $\mathrm{MoO}_{2}$ and $\mathrm{ZnMoO}_{4}$. As it was observed for the sulfided single oxides mixture, the heat released from these exothermic reactions might initiate a direct reaction between 
$\mathrm{ZnS}$, the freshly formed $\mathrm{MoO}_{2}$ and $\mathrm{O}_{2}$ to obtain the $\mathrm{ZnMoO}_{4}$ phase. This sequence can be summarized as: ${ }^{56}$

Firstly, $\mathrm{MoS}_{2}(\mathrm{~s})+3 \mathrm{O}_{2}(\mathrm{~g}) \rightarrow \mathrm{MoO}_{2}(\mathrm{~s})+2 \mathrm{SO}_{2}(\mathrm{~g})$,

$$
\Delta_{\mathrm{r}} \mathrm{H}=-302 \mathrm{~kJ} / \mathrm{mol} \text { of } \mathrm{O}_{2}(\mathrm{~g})
$$

and, $2 \mathrm{ZnMoO}_{3}(\mathrm{~s})+\mathrm{O}_{2}(\mathrm{~g}) \rightarrow 2 \mathrm{ZnMoO}_{4}(\mathrm{~g})$,

no thermochemical data available on $\mathrm{ZnMoO}_{3}$

then, $\mathrm{ZnS}(\mathrm{s})+\mathrm{MoO}_{2}(\mathrm{~s})+2 \mathrm{O}_{2}(\mathrm{~g}) \rightarrow \mathrm{ZnMoO}_{4}(\mathrm{~s})+\mathrm{SO}_{2}(\mathrm{~g})$,

$$
\Delta_{\mathrm{r}} \mathrm{H}=-355 \mathrm{~kJ} / \mathrm{mol} \text { of } \mathrm{O}_{2}(\mathrm{~g})
$$

The homogeneity between zinc and molybdenum components, due to sulfided solid core-shell configuration, could explain the complete oxidation of this material, and the formation of $\mathrm{ZnMoO}_{4}$. Indeed, thermal energy generated by the oxidation of $\mathrm{MoS}_{2}$ and $\mathrm{ZnMoO}_{3}$ phases present in bulk of aggregated particles is evacuated through the $\mathrm{ZnS}$ layer, and might thus favor the $\mathrm{ZnS}$ oxidation and reaction with molybdenum containing phases and lead to the formation of $\mathrm{ZnMoO}_{4}$ phase.

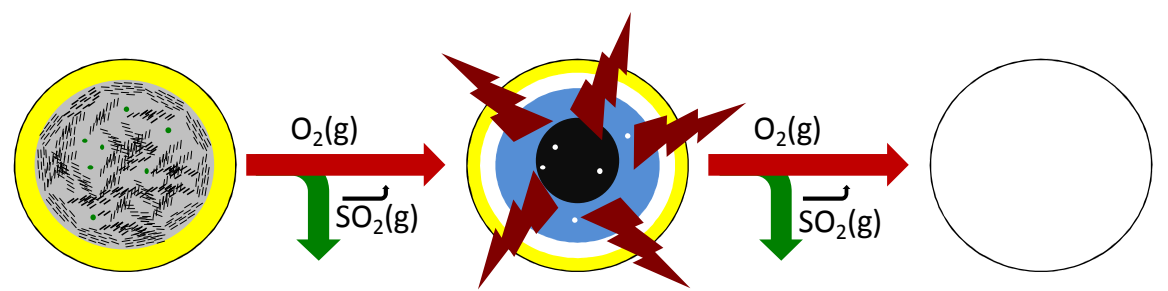

Fig 25 Schematic representation of the sulfided $\mathrm{ZnMoO}_{4}$ mixed oxide regeneration process under isothermal conditions at $500^{\circ} \mathrm{C} . \mathrm{MoS}_{2}$ : black lines on gray surface, $\mathrm{ZnS}$ : dark yellow shape, $\mathrm{ZnMoO}_{3}$ green spots, $\mathrm{MoO}_{2}$ : blue shape, Thermal energy: red lightnings, $\mathrm{ZnMoO}_{4}$ : white shape.

\section{Conclusions}

This study highlighted the interest of the $\mathrm{MoO}_{3}$ addition to $\mathrm{ZnO}$ material. Two types of material were studied: a mixed oxide, $\mathrm{ZnMoO}_{4}$, and a $\mathrm{ZnO}-\mathrm{MoO}_{3}$ single oxides mixture. Their sulfidation and oxidative regeneration properties were investigated through thermogravimetry and in-situ characterizations. Sulfidation of the single oxides mixture was shown to be similar to the combination of the sulfidation of both independent single oxides. However, $\mathrm{ZnO}-\mathrm{MoO}_{3}$ single oxides mixture presents different reactivity under sulfiding and reductive atmospheres compared to $\mathrm{ZnMoO}_{4}$ mixed oxide. Indeed, the mixed oxide sulfidation process leads to $\mathrm{ZnMoO}_{4}$ phase demixing into $\mathrm{ZnS}, \mathrm{MoS}_{2}$ and $\mathrm{ZnMoO}_{3}$. 
Moreover, during the oxidative regeneration, a very significant decrease of the starting regeneration temperature was observed compared to isolated single oxides. The oxidative regenerations of the sulfided single oxide mixtures and mixed oxide are initiated, respectively, at $350^{\circ} \mathrm{C}$ and $300^{\circ} \mathrm{C}$. These temperatures are $250^{\circ} \mathrm{C}$ and $300^{\circ} \mathrm{C}$ lower than the regeneration temperature of a pure $\mathrm{ZnS}$ in experiments conducted in similar operating conditions. For the sulfided mixed oxide regeneration is even complete at $500^{\circ} \mathrm{C}$ under isothermal conditions. Regeneration of sulfided oxides mixture and mixed oxide was thus shown to exhibit synergetic effects, resulting from exothermic oxidative reactions of molybdenum phases. Heat energy released during these reactions is assumed to enhance $\mathrm{ZnS}$ oxidation kinetics at a temperature lower than the previously measured one.

Finally, $\mathrm{ZnMoO}_{4}$ mixed oxide has been shown to exhibit attractive properties for synthesis gas regenerative desulfurization processes. This work included in a multi-technique approach also brings novel and rational insights on these gas-solid reactions, helping for a better understanding of the solid-state transformation mechanisms involved in both sulfidation and oxidative regeneration processes.

In future works, $\mathrm{ZnMoO}_{4}$ mixed oxide should be studied to overcome the issues raised by an industrial application of such regenerable sulfur sorbent material. In particular, breakthrough experiments will be performed to lead to a complete study of the performance of a shaped $\mathrm{ZnMoO}_{4}$ based sorbent during multiple sulfidation-regeneration steps. Attention will be firstly paid on the evolution of the performance of this material during the sulfidation and regeneration cycling, that will be led with model synthesis gas compositions, and various oxidant gas compositions. Experiments with a fully representative coalderived syngas and oxidant that would be used in a practical application, such as air, are then expected. The occurrence of side reactions during the sulfidation step conducted on model synthesis gases, such as methanation or water gas shift reactions, should be also investigated. Attention will be paid to the possible catalytic activity of $\mathrm{ZnMoO}_{4}$ and other zinc and molybdenum phases formed during reaction with $\mathrm{H}_{2} \mathrm{~S}$, as a function of operating conditions. The evolution of the mechanical properties both after sulfidation and highly exothermic regeneration steps with the above synthesis gas and oxidant gas compositions will be also considered.

\section{Acknowledgments}

For IFP Energies nouvelles, the authors gratefully acknowledge Anne-Lise Talleb and AnneSophie Gay for their help performing EFTEM cartographies; Estelle Roche for her help 
performing XRD analyses; Jean-Pierre Reyt and Christine Bounie for technical help on thermogravimetry apparatus.

\section{References}

1. D.Vallentin, Energy Policy, 2008, 36(8), 3198-3211.

2. O.Shinada, A.Yamada, and Y.Koyama, Energy Conversion and Management, 2006, 43(9-12), 1221-1233.

3. M.J.Prins, K.J.Ptasinski, and F.J.J.G.Janssen, Fuel Processing Technology, 2005, 86(4), 375-389.

4. C.Higman and M.J.van der Burgt, Gasification, 2009, Second Edition,

5. H.Schulz, Applied Catalysis A: General, 1999, 186(1-2), 3-12.

6. G.P.Van der Laan and A.A.C.M.Beenackers, Catalysis Reviews-Science and Engineering, 1999, 41(3-4), 255-318.

7. Studies in Surface Science and Catalysis, Fischer-Tropsch Technology, 2004, (152),

8. D.Chiche, C.Diverchy, A.C.Lucquin, F.Porcheron, and F.Defoort, Oil \& Gas Science and Technology, 2013, 68(4), 707-723.

9. E.M.Jallouli, J.P.Larpin, M.Lambertin, and J.C.Colson, Oxidation of Metals, 1977, 11(6), 335-354.

10. C.H.Bartholomew, Applied Catalysis A: General, 2001, 212(1-2), 17-60.

11. O.Borg, N.Hammer, B.C.Enger, R.Myrstad, O.A.E.S.Lindvag, T.H.Skagseth, and E.Rytter, Journal of Catalysis, 2011, 279(1), 163-173.

12. S.S.Pansare and J.D.Allison, Applied Catalysis A: General, 2010, 387(1-2), 224-230.

13. J.F.Akyurtlu and A.Akyurtlu, Gas Separation \& Purification, 1995, 9(1), 1725.

14. D.Karayilan, T.Dogu, S.Yasyerli, and G.Dogu, Industrial \& Engineering Chemistry Research, 2005, 44(14), 5221-5226.

15. R.J.Madon and H.Seaw, Catalysis Reviews, 1977, 15(1), 69-106.

16. C.H.Bartholomew and R.M.Bowman, Applied Catalysis, 1985, 15(1), 59-67.

17. K.Weissermel and H.-J.Arpe, in Chimie organique industrielle, ed. De Boeck Université, 2000, 2.1.2, 19.

18. A.Kohl and R.Nielsen, Gas Purification, Gulf Publishing, 1997, 
19. K.Polychronopoulou and A.M.Efstathiou, Environmental Science \& Technology, 2009, 43(12), 4367-4372.

20. A.Giuffrida, M.C.Romano, and G.G.Lozza, Applied Energy, 2010, 87(11), 3374-3383.

21. P.R.Westmoreland and D.P.Harrison, Environmental Science \& Technology, 1976, 10(7), 659-661.

22. W.F.Elseviers and H.Verelst, Fuel, 1999, 78(5), 601-612.

23. X.M.Meng, W.De Jong, and A.H.M.Verkooijen, Environmental Progress \& Sustainable Energy, 2009, 28(3), 360-371.

24. J.Swisher and K.Schwerdtfeger, Journal of Materials Engineering and Performance, 1992, 1(4), 565-571.

25. J.B.Gibson and D.P.Harrison, Industrial \& Engineering Chemistry Process Design and Development, 1980, 19(2), 231-237.

26. G.Sick and K.Schwerdtfeger, Materials Science and Technology, 1986, 2(2), $159-164$.

27. S.S.Tamhankar, M.Hasatani, and C.Y.Wen, Chemical Engineering Science, 1981, 36(7), 1181-1191.

28. P.Caglayan, S.Yasyerli, I.Ar, G.Dogu, and T.Dogu, International Journal of Chemical Reactor Engineering, 2006, 4(A18),

29. G.Sick and K.Schwerdtfeger, Metallurgical and Materials Transactions B, 1987, 18(3), 603-609.

30. Y.Zeng, S.Zhang, F.R.Groves, and D.P.Harrison, Chemical Engineering Science, 1999, 54(15-16), 3007-3017.

31. J.G.Dunn, Thermochimica Acta, 1997, 300(1-2), 127-139.

32. J.G.Dunn and C.Muzenda, Thermochimica Acta, 2001, 369(1-2), 117-123.

33. R.Dimitrov and B.Boyanov, Journal of Thermal Analysis and Calorimetry, 2000, 61(1), 181-189.

34. M.C.Jha, M.T.Kepworth, and L.K.Baltich, Enhanced Sorbent Durability for Hot Coal Gas Desulfurization., Final Report, DE-AC21-84MC21168.

35. R.V.Siriwardane, J.A.Poston, and G.Evans, Industrial \& Engineering Chemistry Research, 1994, 33(11), 2810-2818.

36. M.Pineda, J.M.Palacios, L.Alonso, E.Garcia, and R.Moliner, Fuel, 2000, 79(8), 885-895. 
37. T.Grindley and G.Steinfeld, Proceedings of the Second Annuals Contractors Meeting on Contaminant Control in Hot Coal Derived Gas Stream., 1981,

38. S.Lew, K.Jothimurugesan, and M.Flytzani-Stephanopoulos, Industrial \& Engineering Chemistry Research, 1989, 28(5), 535-541.

39. Z.Li and M.Flytzani-Stephanopoulos, Industrial \& Engineering Chemistry Research, 1997, 36(1), 187-196.

40. S.O.Ryu, N.K.Park, C.H.Chang, J.C.Kim, and T.J.Lee, Industrial \& Engineering Chemistry Research, 2004, 43(6), 1466-1471.

41. K.Jothimurugesan and S.K.Gangwal, Industrial \& Engineering Chemistry Research, 1998, 37(5), 1929-1933.

42. H.K.Jun, T.J.Lee, and J.C.Kim, Industrial \& Engineering Chemistry Research, 2002, 41(19), 4733-4738.

43. H.K.Jun, T.J.Lee, S.O.Ryu, and J.C.Kim, Industrial \& Engineering Chemistry Research, 2001, 40(16), 3547-3556.

44. H.K.Jun, J.H.Koo, T.J.Lee, S.O.Ryu, C.K.Yi, C.K.Ryu, and J.C.Kim, Energy \& Fuels, 2003, 18(1), 41-48.

45. V.Girard, A.Baudot, D.Chiche, D.Bazer-Bachi, C.Bounie, and C.Geantet, Fuel, 2014, 128, 220-230.

46. T.Weber, J.C.Muijsers, J.H.M.C.van Wolput, C.P.J.Verhagen, and J.W.Niemantsverdriet, The Journal of Physical Chemistry, 1996, 100(33), 14144-14150.

47. L.Neveux, D.Chiche, D.Bazer-bachi, L.Favergeon, and M.Pijolat, Chemical Engineering Journal, 2012, 181-182, 508-515.

48. L.Neveux, D.Chiche, J.Pérez-Pellitero, L.Favergeon, A.S.Gay, and M.Pijolat, Phys. Chem. Chem. Phys., 2013, 15(5), 1532-1545.

49. D.Wang, J.Yu, L.Chang, and D.Wang, Chemical Engineering Journal, 2011, 166(1), 362-367.

50. P.Afanasiev, Comptes Rendus Chimie, 2008, 11(1-2), 159-182.

51. I.Bezverkhyy, J.Skrzypski, O.Safonova, and J.P.Bellat, J. Phys. Chem. C, 2012, 116(27), 14423-14430.

52. A.D.Smigelkas and E.O.Kirkendall, Trans. AIME, 1947, 171, 130-142.

53. J.C.Muijsers, T.Weber, R.M.Vanhardeveld, H.W.Zandbergen, and J.W.Niemantsverdriet, Journal of Catalysis, 1995, 157(2), 698-705. 
54. S.S.Tamhankar, M.Bagajewicz, G.R.Gavalas, P.K.Sharma, and M.FlytzaniStephanopoulos, Industrial \& Engineering Chemistry Process Design and Development, 1986, 25(2), 429-437.

55. Z.D.Zivkovic and J.Sestak, Journal of Thermal Analysis and Calorimetry, 1998, 53(1), 263-267.

56. Outotec, Research. HSC Chemistry [6.1] Outotec Research. 2007.

Ref Type: 